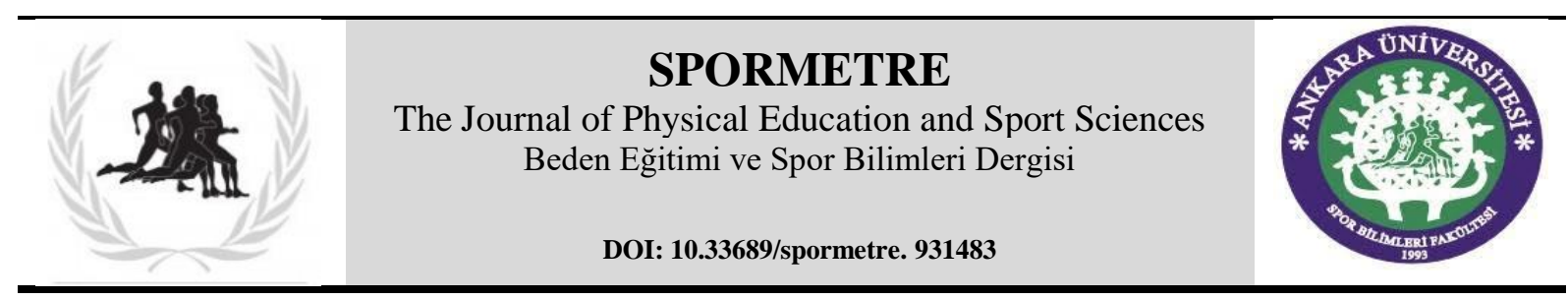

Geliş Tarihi (Received): 02.05.2021～Kabul Tarihi (Accepted): 08.10.2021 Online Yayın Tarihi (Published): 30.12 .2021

\title{
VEGAN SPORCULARDA BESLENME VE SPORTIF PERFORMANS
}

\author{
Duygu İpekçi ${ }^{1 *}$ (D), Neşe Toktaş ${ }^{1}$ (D) \\ ${ }^{1}$ Akdeniz Üniversitesi, Spor Bilimleri Fakültesi, ANTALYA
}

\begin{abstract}
Öz: Günümüzde hem genel popülasyon hem de sporcular arasında vegan beslenmeye olan ilgi artmıştır. Vegan beslenme, et, süt, deniz ürünleri, yumurta ve bal gibi hayvansal besinlerin tüketilmediği, sadece bitkisel besinlerin tüketildiği bitkisel kaynaklı beslenmenin bir modelidir. Teorik olarak, vegan beslenme ile alınan karbonhidratın fazla olmasının vücuttaki glikojen depolarını arttırabileceği, tüketimi artan fitokimyasallar ve antioksidanların uzun süreli egzersiz ile ilişkili oksidatif stresi azaltabileceği ve genel bağışıklığı arttırabileceği, meyve ve sebze tüketiminin fazla olmasından dolayı, kas pH'sındaki artışın alkali bir ortam oluşturarak kastaki asiditeyi dengeleyebileceği, böylece vegan beslenmenin sportif performansı arttıracağı belirtilmektedir. İyi planlanmamış vegan bir diyet ile günlük besin öğesi ihtiyaçları eksik kalabilir, sağlı ve performans olumsuz olarak etkilenebilir. Bu derleme, güncel literatür eşliğinde vegan sporcularda beslenmeyi ve vegan beslenmenin sportif performans üzerindeki etkilerini incelemeyi amaçlamaktadır.
\end{abstract}

Anahtar Kelimeler: Vegan, vegan sporcu, sportif performans, sağl1k

\section{EATING HABITS AND SPORTIVE PERFORMANCE OF VEGAN ATHLETES}

\begin{abstract}
The relevance of veganism has been increased nowadays both in the general population and athletes. The vegan diet is a type of plant-based diet that does not consume animal-sourced products such as meat, milk, seafood, eggs and honey. It has been argued that, in theory, the vegan diet could improve sportive performance because; high intake of carbohydrate may increase glycogen stores, high intake of phytochemicals and antioxidants may reduce oxidative stress and may improve the immune system. Increased fruit and vegetable consumption could result in higher muscle $\mathrm{pH}$, thus balance muscle acidity. A poorly planned vegan diet may adversely affect health and sportive performance due to a lack of daily nutrient intake. This review aims to investigate the eating habits of vegan athletes and the effects of the vegan diet on sport performance based on the up-to-date literature.
\end{abstract}

Key Words: Vegan, vegan athletes, sportive performance, health

\section{GİRIŞ}

Vegan beslenme, bitkisel kaynaklı beslenmenin bir çeşidi olup et, süt, deniz ürünleri, yumurta ve bal gibi hiçbir hayvansal ürünün tüketilmediği bir beslenme modelidir (Lemale ve ark., 2019). Etik ilkeler ve sağlık başta olmak üzere, lezzet, çevresel ve dini nedenler gibi faktörlerden dolayı insanlar vegan beslenmeyi tercih etmektedir (Janssen ve ark., 2016).

Toplumda vegan beslenmenin kabul görmesi, sporcular arasında da vegan beslenmeye ilgiyi artırmıştır. Dünyaca ünlü sporcular da dahil olmak üzere vejetaryen ve vegan sporcuların sayısı her geçen gün artmakta olup yakın gelecekte amatör ve profesyonel tüm seviyelerdeki vegan sporcu sayısında artış beklenmektedir (Katharina, 2020). Bu gelişmelere paralel olarak vegan beslenme ile ilgili bilimsel çalışma sayısı da artmaktadır (Devrim-Lanpir ve ark., 2021). 
Sebze, meyve, tahıl ve kuruyemiş tüketiminin daha fazla olmasından dolayı bitkisel kaynaklı beslenme ile daha yüksek oranda lif ve doymamış yağ asidi, daha düşük oranda toplam yağ ve doymuş yağ asidi alınır (Vanacore ve ark., 2018). Omnivorlar ile karşılaştırıldığında, bitkisel kaynaklı beslenen bireylerin beden kütle indeksi (BKI), kan lipit düzeyleri, açlık kan glukoz değerleri gibi kronik hastalıklar için belirleyici olan risk faktörlerinin daha düşük olduğu görülmüştür (Dinu ve ark., 2017). Fakat yeterli ve dengeli olmayan, zenginleştirilmemiş bitkisel kaynaklı diyetler ile protein, $B_{12}$ vitamini, D vitamini, omega 3 (n-3), kalsiyum, demir ve çinko gibi bazı besin öğelerinin yetersiz alınması söz konusu olabilir (Appleby ve Key, 2016; Rocha ve ark., 2019).

Vegan beslenmenin sportif performansa etkileri üzerine güncel literatürde sınırlı sayıda çalışma bulunmaktadır. Vegan ve omnivor beslenmenin karşılaştırıldığı çalışmalarda hem kuvvet hem de dayanıklılık performansında iki diyet modeli arasında fark bulunmamıştır (Boutros ve ark., 2020; Hernández-Martínez ve ark., 2020; Leischik ve Spelsberg, 2014; Lynch ve ark., 2016; Nebl ve ark., 2019). Bu konu ile ilgili daha fazla sayıda çalışmaya ihtiyaç olduğu belirtilmektedir (Craddock ve ark., 2016). Bitkisel kaynaklı diyetlerin sportif performans üzerinde olumlu etkisinin olabileceği ile ilgili literatürde üç olası teoriden bahsedilmektedir. İlk teori, vejetaryen diyetle alınan karbonhidratın fazla olmasının vücuttaki glikojen depolarını arttırarak performans artışı sağlayabileceğidir. Bitkisel kaynaklı besinler ile tüketimi artan fitokimyasallar ve antioksidanların uzun süreli egzersiz ile ilişkili oksidatif stresi azaltabileceği ve genel bağışıklığı arttırabileceği ise ikinci teoridir (Craddock ve ark. 2016). Üçüncü teori, kas içi asiditenin azalmasına bağlı olarak yüksek şiddetli egzersiz performansının artmasıdır (Carr ve ark., 2011; Craddock ve ark., 2016). Omnivor diyetlere kıyasla bitkisel kaynaklı diyetlerde hayvansal protein alımının düşük, meyve ve sebze tüketiminin daha fazla olmasından dolayı, kas pH'sındaki artış alkali bir ortam oluşturarak kastaki asiditeyi dengelemektedir (Deriemaeker ve ark., 2010; Hietavala ve ark., 2015).

$\mathrm{Bu}$ derlemede güncel literatür eşliğinde vegan sporcularda beslenme ve sportif performans konularına değinilmiş, vegan sporcular için beslenme stratejilerinden bahsedilmiştir.

\section{VEGAN BESLENME VE SAĞLIK İLIŞKIŞ̧̇}

Bitkisel kaynaklı beslenmenin sağlığa olan olumlu etkilerinin gözlemlenmesiyle batı toplumlarında son yıllarda popülerliği ve benimsenme oranı artmıştır (Medawar ve ark., 2019). Vejetaryenlik farklı diyet uygulamalarını kapsayan heterojen ve geniş kapsamlı bir terimdir (Cramer ve ark., 2017). Vejetaryen beslenme ile genelde diyetten, et, kümes hayvanları ve benzeri ürünlerin çıkarılmasıyla birlikte diyette meyve, sebze, tahıl, kurubaklagil ve yağlı tohum tüketimine odaklanılmaktadır (Sakkas ve ark., 2020). Vejetaryen diyet türleri, peskolakto vejetaryen, lakto-ovo vejetaryen, lakto-vejetaryen, ovo-vejetaryen, pesko-vejetaryen ve vegan diyet olup bu diyet türlerinin tanımları tablo 1'de özetlenmiştir. Bu çalışmada sadece vegan diyetin etkileri sunulmaktadır.

Vegan beslenme, et, balık, kabuklu deniz ürünleri, süt ve süt ürünleri, yumurta ve bal gibi hayvansal hiçbir ürünün tüketilmemesi olarak tanımlanır (Wirnitzer ve ark., 2019). Vegan diyet de kendi içerisinde türlere ayrılır, bunlardan biri makrobiyotik diyet olarak bilinen belirli meyve ve sebzeleri diyetten çıkaran ve diyetin \%50-60'1nı tam tahıllar oluşturacak şekilde sebze, bakliyat, algler ve fermente soya ürünlerini içeren bir beslenme düzenidir (Lemale ve ark., 2019). Öte yandan 48 derecenin üzerinde işlem görmüş hiçbir besini tüketmeyen, sadece hayvansal olmayan organik ve taze besinleri tüketen, çiğ beslenme olarak da adlandırılan 
vitarian (Rocha ve ark., 2019) ve sadece taze ve kuru meyveleri, tohumları ve bazı sebzeleri tüketen früktaryen türü bulunur (Agnoli ve ark., 2017).

Tablo 1. Omnivor beslenme ve vejetaryen diyet türlerinin sinıflandırılması

\begin{tabular}{|c|c|c|c|c|c|c|}
\hline Diyet Tipi & Tanım & $\begin{array}{l}\text { Kurmızı } \\
\text { et }\end{array}$ & $\begin{array}{l}\text { Kümes } \\
\text { hayvanı }\end{array}$ & Balık & $\begin{array}{l}\text { Süt } \\
\text { ürünleri }\end{array}$ & Yumurta \\
\hline Omnivor & $\begin{array}{l}\text { Kırmızı et, kümes } \\
\text { hayvanları, balık, süt } \\
\text { ürünleri ve yumurta tüketir. }\end{array}$ & $\sqrt{ }$ & $\sqrt{ }$ & $\sqrt{ }$ & $\sqrt{ }$ & $\sqrt{ }$ \\
\hline $\begin{array}{l}\text { Pesko-lakto- } \\
\text { ovo- } \\
\text { vejetaryen }\end{array}$ & $\begin{array}{l}\text { Balık, süt ürünleri ve } \\
\text { yumurta tüketirken kırmızı } \\
\text { et ve kümes hayvanlarını } \\
\text { tüketmez }\end{array}$ & $\mathrm{X}$ & $\mathrm{X}$ & $\sqrt{ }$ & $\sqrt{ }$ & $\sqrt{ }$ \\
\hline $\begin{array}{l}\text { Lakto-ovo } \\
\text { vejetaryen }\end{array}$ & $\begin{array}{l}\text { Süt ürünleri ve yumurtayı } \\
\text { tüketirken kırmızı et, } \\
\text { kümes hayvanları ve balık } \\
\text { tüketmez }\end{array}$ & $\mathrm{X}$ & $\mathrm{X}$ & $\mathrm{X}$ & $\sqrt{ }$ & $\sqrt{ }$ \\
\hline $\begin{array}{l}\text { Lakto- } \\
\text { vejetaryen }\end{array}$ & $\begin{array}{l}\text { Süt ürünleri tüketirken } \\
\text { kırmızı et, kümes } \\
\text { hayvanları, balı ve } \\
\text { yumurta tüketmez }\end{array}$ & $X$ & $X$ & $X$ & $\sqrt{ }$ & $X$ \\
\hline $\begin{array}{l}\text { Ovo- } \\
\text { vejetaryen }\end{array}$ & $\begin{array}{l}\text { Yumurta tüketirken kırmızı } \\
\text { et, kümes hayvanları, balık, } \\
\text { süt ürünleri tüketmez }\end{array}$ & $\mathrm{X}$ & $\mathrm{X}$ & $\mathrm{X}$ & $\mathrm{X}$ & $\sqrt{ }$ \\
\hline $\begin{array}{l}\text { Pesko- } \\
\text { vejetaryen }\end{array}$ & $\begin{array}{l}\text { Balık tüketirken kırmızı et, } \\
\text { kümes hayvanları, yumurta } \\
\text { ve süt ürünleri tüketmez }\end{array}$ & $\mathrm{X}$ & $\mathrm{X}$ & $\sqrt{ }$ & $\mathrm{X}$ & $\mathrm{X}$ \\
\hline Vegan & $\begin{array}{l}\text { Kırmızı et, } \\
\text { hayvanları, } \\
\text { ürünleri balık, sür } \\
\text { tüketmez }\end{array}$ & $\mathrm{X}$ & $\mathrm{X}$ & $\mathrm{X}$ & $\mathrm{X}$ & $\mathrm{X}$ \\
\hline
\end{tabular}

Kaynak: (Craddock ve ark., 2016).

Omnivor beslenmeye kıyasla vegan diyetler daha yüksek diyet lifi, magnezyum, folik asit, C ve E vitamini, non-hem demir ve fitokimyasal içerir. Enerji, doymuş yağ, kolesterol, n-3 yağ asidi, $\mathrm{D}$ ve $\mathrm{B}_{12}$ vitamini, kalsiyum ve çinko içeriği daha düşüktür (Craig, 2009). Bitkisel kaynaklı beslenmenin, tip 2 diyabet, bazı kanser türleri, kardiyovasküler hastalıklar, hipertansiyon, obezite, metabolik sendrom, katarakt, bazı mental hastalıklar, kronik böbrek hastalıkları, depresyon riskini azalttığı bilinirken, mikrobiyota sağlığını geliştirdiği ve gebelik sürecinin de sağlıklı geçmesini desteklediği bilinmektedir (Marsh ve ark., 2012; Sakkas ve ark., 2020).

Düşük yağlı vegan diyetin tip 2 diyabetli bireylerde glisemik kontrol ve kardiyovasküler risk faktörleri üzerine etkilerini inceleyen bir çalışmada, 22 hafta boyunca 49 bireye düşük yağlı vegan diyet, 50 bireye Amerikan Diyabet Derneği (ADA)'nin önerileri doğrultusunda hazırlanmış bir diyet uygulanmıştır. Çalışma çıktılarında; HbA1c değerinin vegan grupta $\% 0,96$, ADA grubunda \%0,56 düştüğü, vücut ağırlığının vegan grupta $6,5 \mathrm{~kg}$ ve ADA grubunda $3,1 \mathrm{~kg}$ azaldığ 1 tespit edilmiştir. Sonuçta, hem düşük yağlı bir vegan diyetin hem de ADA yönergelerine dayalı bir diyetin, tip 2 diyabetik hastalarda glisemik kontrolü ve lipid kontrolünü iyileştirdiği raporlanmıştır (Barnard ve ark., 2006).

Kesitsel bir çalışmada 22 vegan ve 30 omnivor amatör koşucunun kalp morfolojisi ve fonksiyonunun ekokardiyografik karşılaştırılmasında, omnivorlara kıyasla 
veganların longitudinal strain (vegan: $-\% 20.5$ 'e karş1 omnivor: -\%19.6) ile belirlenen sistolik fonksiyonunun ve E-dalga hızları (vegan: $87 \mathrm{~cm} / \mathrm{s}^{\prime}$ ye karşı omnivor: $78 \mathrm{~cm} / \mathrm{s}$ ) ile belirlenen diyastolik fonksiyonunun daha yüksek olduğu gösterilmiştir (Król ve ark., 2020).

Avrupa Kanser ve Beslenmeye Yönelik Araştırma çalışmasının (EPIC-Oxford) Oxford kohortunda (37875 sağlıklı kadın ve erkek), dört diyet grubunun (et tüketiciler, balık tüketiciler, vejetaryenler ve veganlar) BKI'leri karşılaştırıldığında; et tüketicilerin en yükssek BKİ'ye (erkek: $24.41 \mathrm{~kg} / \mathrm{m}^{2}$, kadın: $23.52 \mathrm{~kg} / \mathrm{m}^{2}$ ) sahipken veganların en düşük değere (erkek: 22.49 $\mathrm{kg} / \mathrm{m}^{2}$, kadın: $21.98 \mathrm{~kg} / \mathrm{m}^{2}$ ) sahip olduğu belirlenmiştir (Spencer ve ark., 2003).

Diyet modelinin mikrobiyata üzerine etkisini inceleyen bir çalışmada, 144 vejetaryen, 105 vegan ve eşit sayıda omnivor katılımcının fekal analiziyle, toplam Bacteroides spp., Bifidobacterium spp., Escherichia coli ve Enterobacteriaceae spp. bakterilerinin sayıları değerlendirilmiştir. Vegan numunelerde kontrollere göre sıralanan bakteriler anlamlı olarak daha düşük bulunmuştur. Diğer bakterilerde ise (E. coli biovars, Klebsiella spp., Enterobacter spp., diğer Enterobacteriaceae, Enterococcus spp., Lactobacillus spp., Citrobacter spp. ve Clostridium spp.) fark bulunmamıştır. Ek olarak, vegan veya vejetaryen katılımcıların fekal analizinde, kontrollere göre önemli ölçüde daha düşük $\mathrm{pH}$ seviyesi tespit edilmiştir. Tüm alt gruplarda dışkı pH'ı ile E. coli ve Enterobacteriaceae sayıları arasındaki korelasyon anlamlı bulunmuştur (Zimmer ve ark., 2012).

Vegan beslenmenin hipertansiyon riskini \%75, tip 2 diyabet riskini \%47-78 ve tüm kanser türleri için kanser görülme sıklığını \%14 azalttığı bildirilmiştir (Le ve Sabaté, 2014). Ayrıca bitkisel kaynaklı beslenmenin kan basıncı ve kan viskositesini düşürdüğü de tespit edilmiştir (Storz ve Helle, 2019; Yokoyama ve ark., 2014). Vegan beslenmenin mortalite üzerine etkisinin incelendiği geniş bir kohort çalışmada, bitkisel kaynaklı beslenmenin mortalite oranını azalttığı bildirilmektedir (Orlich ve ark., 2013).

Vegan beslenmenin sağlık üzerine etkileri ile ilgili yapılan çalışmaların bazılarında katılımcıların vegan beslenme sürelerinin verilmesi ( 2 yıldan daha uzun süre, 3 ay, 6 ay, 11 ay gibi), bazı çalışmalarda verilmemesinden dolayı uzun süreli uygulanan vegan beslenmenin sağlık üzerine etkileri ile ilgili daha fazla çalışmaya ihtiyaç olduğu belirtilmektedir (Appleby ve Key, 2016).

\section{Vegan beslenmenin bazı biyokimyasal değerler üzerine etkisi}

Bitkisel kaynaklı beslenmenin toplam kolesterol, HDL kolesterol ve LDL kolesterolü düşürdüğü belirtilmektedir (Dinu ve ark., 2017; Medawar ve ark., 2019; Oussalah ve ark., 2020; Yokoyama ve ark., 2017). En az 6 aydır vegan beslenen 12619 vegan ve 179630 omnivoru içeren, 1960-2018 yılları arasında yapılmış 40 gözlemsel çalışmanın değerlendirildiği bir meta analizde; trigliserid değerleri için toplamda 2731 vegan 51814 kontrol grubundan bireyi içeren 29 çalışma değerlendirilmiş, veganların kontrol grubuna göre daha düşük trigliserid (-0.14 mmol/l [95\% güven aralığ1 -0.24 ile -0.05] düzeyine sahip olduğu bulunmuştur. Ancak Asya bölgesi değerlendirildiğinde, tam tersine, veganların kontrol grubundan daha yüksek $(0.15$ [95\% güven aralığ 0.02 ila 0.28] trigliserid düzeyine sahip olduğu tespit edilmiştir. Bu meta analizde Asya çalışmalarının analizdeki tüm veganların \% 82'sini oluşturduğu, analize alınan çalışmaların sonuçlarındaki farklılıkların derecesi ile ilişkili olan anlamlı bir heterojenitenin var olduğu, yayın yanlılı̆̆ı riskinin bulunduğu belirtilmiştir (Benatar ve Stewart, 2018). 
Açlık insülin seviyesi ve insülin hassasiyetine olan etkinin incelendiği, 279 vejetaryen (73 vegan, 206 lakto-ovo vejetaryen) ve 279 omnivorun değerlendirildiği bir çalışmada, veganlarda insülin direncinin $[(\beta=-0.16,95 \%$ güven aralığı: $(-0.30,-0.01)]$ ve açlık insülin $[(\beta=-0.17$, $95 \%$ güven aralığı: $(-0.32,-0.03)]$ değerlerinin daha düşük olduğu tespit edilmiştir (Cui ve ark., 2019). Tip 2 diyabet hastalarında, Kore Diyabet Derneği'nin önerdiği omnivor diyet modeli ve vegan diyet uygulamalarının karşılaştırıldığı bir çalışmada, on iki haftalık süreçte her iki diyet uygulamasının da HbA1c değerini düşürdüğü gözlemlenirken, vegan grupta glisemik kontrolün daha iyi olduğu raporlanmıştır (Lee ve ark., 2016). Tip 2 diyabet hastalarında (n: 74), 12 haftalık diyet ve aerobik egzersizden sonra aynı kalori kısıtlamasına (-500 kkal/gün) sahip bitkisel gidalara dayalı vegan ve geleneksel diyetin fiziksel uygunluk ve dinlenme enerji harcaması üzerindeki etkilerinin karşılaştırıldığ bir çalışmada, daha düşük glisemik indeksli bir diyetin mitokondriyal oksidasyonu artırdığı önceki çalışmalara uygun olarak gösterilmiştir (Veleba ve ark., 2016). Ek olarak vejetaryen grubun karbonhidratları daha iyi kullanabildikleri bulunmuş olup insülin duyarlılığının da arttığı raporlanmıştır. Raporlanan değişikliklerin vejetaryen grupta maksimum performans ve maksimum oksijen kullanım kapasitesinin artma nedenleri olduğu düşünülmektedir (Veleba ve ark., 2016).

Egzersize bağlı kas hasarının, değişen derecelerde inflamasyona neden olabileceği bilinmektedir (Pedlar ve ark., 2019). İnflamasyon belirteçleri üzerine yapılan çalışmalarda veganlar ve omnivorlar arasında hsCRP, adiponektin, ICAM-1, IL-18, IL-1 RA, omentin-1 veya resistin arasında anlamlı bir farklılık belirtilmemiş (Menzel ve ark., 2020), en az iki yıllık süre ile vejetaryen diyet ile beslenen bireylerin hsCRP değerinde belirgin bir düşüşe rastlanmıştır (Haghighatdoost ve ark., 2017). Gruplar arasındaki bu farklılığın dayanıklılık performansı esnasında sitokin üretiminde de farklılıklar oluşturabileceği düşünülmektedir (Craddock ve ark., 2020).

B 12 eksikliği serum homosistein seviyelerinin yükselmesi ile ilintili olmakla beraber metilmalonik asit (MMA), holo-transkobalamin II (holo-TC) veya her ikisinin seviyelerine bakılarak tespit edilebilmektedir (holo-TC $<35 \mathrm{pmol} / \mathrm{L}$; idrar MMA (> $4.0 \mathrm{mg} / \mathrm{mg}$ kreatinin); serum MMA> $260 \mathrm{mmol} / \mathrm{L}$ ile $>0.75 \mathrm{mmol} / \mathrm{L}$ ). AMSTAR2 kriterlerine göre orta veya yüksek kaliteli inceleme olarak sınıflandırılan vejetaryenler ile ilgili yapılmış, aralarında veganların da bulunduğu 20 gözlemsel ve girişimsel araştırmayı derleyen meta analizde, omnivorlara (11.03 $\mathrm{mmol} / \mathrm{L}, \mathrm{SD}=2.89)$ kiyasla veganlarda $(16.41 \mathrm{mmol} / \mathrm{L}, \mathrm{SD}=4.8)$ ortalama homosistein konsantrasyonunun anlamlı olarak yükssek seyrettiği raporlanmıştır (Oussalah ve ark., 2020). $\mathrm{B}_{12}$ vitamini eksikliği, oksijen taşınmasının azalmasına neden olan makrositik anemi ile sonuçlanabilir, bu durum sportif performansı azaltabilir. Uzun süreli $\mathrm{B}_{12}$ vitamini eksikliğinin geri dönüşü olmayan nörolojik hasara neden olabileceği de bilinmektedir (Zhou ve ark., 2014).

Veganlarda serum demir ve hemoglobin seviyeleri omnivorlara göre farklılık göstermese de serum ferritin seviyelerinin düşük olduğu raporlanmıştır (Nebl ve ark., 2019). Düşük serum ferritin konsantrasyonunun genellikle demir eksikliğinin teşhisi olduğu bilinmektedir. Demir eksikliği, hemoglobin içeriğini ve oksijen taşıma kapasitesini azaltması nedeniyle performansta bir düşüşe neden olabilir (San-Millán, 2019). Farklı performans seviyelerinde antrene 20 erkek 20 kadın tırmanışçı ile yapılmış bir çalışmada, 11 vejetaryen (5 vegan; 6 vejetaryen), 29 omnivor katılımcının değerlendirilmesiyle, kadınlarda vegan ve vejetaryen tırmanışçlar arasında serum ferritin için anlamlı bir fark bulunmamıştır $\left(30.7 \pm 11.1\right.$ 'e karşı $37.0 \pm 24 \mu \mathrm{g} \cdot \mathrm{L}^{-}$ $\left.{ }^{1}\right)$. Bununla birlikte, vegan/vejetaryenlerin bir arada serum ferritini, kadın omnivorlarla karşılaştırıldığında $\left(33.2 \pm 14.8^{\prime}\right.$ e karşı $\left.57.5 \pm 24 \mu \mathrm{g} \cdot \mathrm{L}^{-1}\right)$ önemli ölçüde daha düşük olduğu tespit edilmiştir (Gibson-Smith ve ark., 2020). Vejetaryen sporcular arasında demir durumunun 
dayanıklılık veya direnç performansı üzerindeki etkisi açıklığa kavuşturulmamıştır (Zhou ve ark., 2014).

Plazma $25(\mathrm{OH})$ D seviyesinin omnivorlara kıyasla veganlarda daha düşük olduğu gözlemlenmiştir (Crowe ve ark., 2011; Ho-Pham ve ark., 2012; Outila ve ark., 2000). Gruplar arasındaki farklılık yaz mevsiminde en az iken kış mevsimde en yüksek seviyededir (Crowe ve ark., 2011). Derleme bir makalede ise D vitamininin vücutta sentezlenmesi nedeniyle vegan ve omnivor gruplar arasında plazma $25(\mathrm{OH}) \mathrm{D}$ seviyelerinde farklılık olmayacağ (Li, 2011).

\section{Vegan beslenmenin vücut kompozisyonu üzerine etkisi}

Vejetaryenler ile birlikte veganların incelendiği birçok derleme çalışmada omnivorlara göre veganların daha düşük BKI'ye sahip olduğu belirtilmiştir (Craig ve Mangels, 2009; Dinu ve ark., 2017; Le ve Sabaté, 2014; Lynch ve ark., 2016).

Veganların kardiyometabolik risk faktörlerinin araştırıldı̆̆ı, 1960-2018 yılları arasında yapılmış 40 gözlemsel çalışmanın değerlendirildiği meta analizde, BKİ için 12241 vegan ve 169385 kontrol grubunda olan bireyi içeren 37 çalışma incelenmiş, Asya bölgesinde yapılan çalışmalarda vegan ve kontrol grubunun BKİ'leri farklı değilken, Asya bölgesi dışındaki çalışmalarda farklılık bulunmuştur. Aynı meta analizde 2288 vegan ve 50571 kontrol grubunu oluşturan bireyi içeren 10 çalışmada, bireylerin bel çevresi değerlendirildiğinde, Asya çalışmalarında vegan ve kontrol grubunun bel çevrelerinde farklılık bulunmazken, Asya dışı çalışmalarda veganların bel çevresi kontrol grubuna göre daha düşük bulunmuştur. Hem BKI hem de bel çevresi sonuçları için meta analizde anlamlı heterojenitenin olduğu, fakat yayın yanlılığının bulunmadığı belirtilmiştir (Benatar ve Stewart, 2018).

Başka bir meta analizde, 1151 bireyi içeren, 12 randomize kontrollü çalışma değerlendirilmiş, vejetaryen olmayan diyetlere göre özellikle vegan diyetin daha fazla ağırlık kaybına neden olduğu bildirilmiştir (Huang ve ark., 2016).

Rekreasyonel koşan 24 vegan, 26 lakto-ovo-vejetaryen ve 26 omnivor bireyin katılımıyla gerçekleştirilen kesitsel bir çalışmada, bireylerin bipolar biyoelektrik impedans analizörü (BIA) ile yapılan ölçümlerinde, diyet grupları arasında BKİ, yağsız vücut kütlesi (YVK) ve yağ yüzdesi arasındaki farklılıklar anlamlı bulunmamıştır (Nebl ve ark., 2019).

Farklı branşlarda (maraton, triatlon, bisiklet veya diğer ultra dayanıklılık branşları) yarışan 27 vejetaryen (15 vegan) 43 omnivor elit dayanıklılık sporcusuyla yapılan kesitsel bir çalışmada sporcuların DEXA ile alınan ölçümlerinde, diyet grupları arasında, vücut kütlesi ve YVK arasındaki farklılıklar anlamlı bulunmuştur. Kadın vejetaryenlerin, kadın omnivorlara kıyasla daha düşük toplam vücut kütlesine ve YVK'ye sahip olma eğiliminde olduğu tespit edilmiştir (sırasıyla -\%11 ve -\%7). Ancak, gruplar arasında vücut yağ yüzdesi farkı anlamlı bulunmamıştır (Lynch ve ark., 2016).

Sonuç olarak bu çalışmalar değerlendirildiğinde, aralarında veganların da bulunduğu vejetaryen bireylerin omnivorlara göre daha düşük BKİ'ye, YVK'ne ve bel çevresine sahip olduğunu belirten çalışmaların yanı sıra (Huang ve ark., 2016; Lynch ve ark., 2016) anlamlı farklılık olmadığını gösteren çalışmalar da bulunmaktadır (Benatar ve Stewart, 2018). Gruplar arasındaki yağ yüzdesi farkı kadın veganlarda daha düşük gözlemlense de fark anlamlı bulunmamıştır (Lynch ve ark., 2016). 


\section{VEGAN BESLENME VE SPORTIF PERFORMANS}

\section{Vegan beslenme ve dayanıklılık performansı}

Orta-yüksek şiddetli aerobik egzersizler esnasında karbonhidratlar birincil enerji kaynağı olarak bilinmektedir. Dayanıklılık performansını artırabilmek için karbonhidratların sadece egzersizden hemen önce değil uzun vadeli tüketim durumu da önemlidir (Barnard ve ark., 2019). Bitkisel kaynaklı beslenme tahıl, kurubaklagil, kök sebze ve kompleks karbonhidrat açısından zengindir (Cullum-Dugan ve Pawlak, 2015). Ayrıca bitkisel kaynaklı beslenmenin bağışıklığı arttırdığg olarak etkileyeceği belirtilmekte fakat yeterli çalışma olmamasından dolayı belirsizlikler devam etmektedir (Craddock ve ark., 2020). Düşük proteinli ve alkali içeriği yüksek sebze ve meyve tüketiminin kan pH'sını bazik yönde değiştirebileceği, bu durumun daha yüksek bir aerobik kapasite oluşturabileceği düşünülmektedir (Hietavala ve ark., 2012)

Fiziksel olarak aktif (haftada 150- 200 dk'lık aerobik fiziksel aktivite yapan), 18-35 yaş arası, 28 vegan ve 28 omnivor kadın üzerinde yapılan bir çalışmada, diyet türünün dayanıklılık performansı ve kas kuvveti üzerine etkileri araştırılmıştır. Katılımcılar en az iki yıldır tercih ettikleri beslenme modelini sürdüren bireylerden oluşmaktadır. Katılımcıların antropometrik ölçümleri alınmış, maksimum oksijen tüketimi ( $\mathrm{VO}_{2}$ maks) ve kas kuvvetini belirlemek için testler yapılmış, ayrıca submaksimal dayanıklılık testi $\left(\mathrm{VO}_{2}\right.$ maks'ın \%70'i) uygulanmıştır. Çalışma sonucunda; veganların omnivorlara göre $\mathrm{VO}_{2}$ maks'larının (veganlar: $44.5 \pm 5.2$ $\mathrm{mL} / \mathrm{kg} / \mathrm{dk}$, omnivolar: $41.6 \pm 4.6 \mathrm{~mL} / \mathrm{kg} / \mathrm{dk}$ ) ve submaksimal dayanıklılık testi sonuçlarının daha yüksek (veganlar: $12.2 \pm 5.7 \mathrm{dk}$, omnivorlar: $8.8 \pm 3.0 \mathrm{dk}$ ) olduğu raporlanmıştır. $\mathrm{Bu}$ çalışmada gruplar arasındaki farklılığı oluşturan mekanizmalardan birinin veganların daha yüksek miktarda karbonhidrat tüketmesi (veganlar: $303.4 \pm 90.5 \mathrm{~g}$, omnivorlar: $225.4 \pm 123.2$ g), bir diğer mekanizmanın, uygun oksidatif stres ve inflamasyon profili olabileceği düşünülmüştür (Boutros ve ark., 2020).

Rekreasyonel koşan, 24 vegan, 26 lakto-ovo vejetaryen ve 26 omnivor katılımcının maksimum egzersiz kapasitesini belirlemek için yapılan çalışmada, katılımcılara tükenene kadar kademeli bisiklet ergometresi testi uygulanmış, test esnasında arteriyel laktat ve glukoz konsantrasyonları ölçümü için katılımcılardan kan örnekleri alınmıştır. Her üç grupta maksimum güç çıktısı benzerdir (omnivor: $4.15 \pm 0.48 \mathrm{~W} / \mathrm{kg}$, lakto-ovo vejetaryen: $4.20 \pm 0.47 \mathrm{~W} / \mathrm{kg}$, vegan: $4.16 \pm$ $0.55 \mathrm{~W} / \mathrm{kg}$ ). Ayrica maksimum laktat seviyelerinde de bir farklılık gözlemlenmemiştir (omnivor: $11.3 \pm 2.19 \mathrm{mmol} / \mathrm{L}$, lakto-ovo vejetaryen: $11.0 \pm 2.59 \mathrm{mmol} / \mathrm{L}$, vegan: $11.9 \pm 1.98 \mathrm{mmol} / \mathrm{L})$. Çalışma verileri diyetin egzersiz kapasitesi açısından ne avantaj ne de dezavantaja sahip olduğunu göstermiştir (Nebl ve ark., 2019).

Bir vaka raporunda, 48 yaşında, çiğ vegan diyetle beslenen erkek ultra-triatlet ile aynı yaş ve cinsiyette omnivor beslenen ultra-triatlet karşılaştırılmıştır. Bireylerin ekokardiyografik bulguları incelenmiş ve oksijen tüketimleri değerlendirilmiştir. Vegan sporcunun oksijen tüketiminin daha yüksek olduğu, ekokardiyografik parametrelerinden, diyastol sonu hacim, vuruş hacmi ve sol ventrikül diyastol sonu çapının omnivor beslenen sporcudan yüksek olduğu, fakat bu değerlerin normal sınırları aşmadığı belirtilmiştir (Leischik ve Spelsberg, 2014).

Aralarında veganların da yer aldığı, 21-58 yaş arası, 27 vejetaryen ( 9 erkek ve 6 kadın vegan; 5 erkek ve 7 kadın lakto-ovo vejetaryen) ve 43 omnivor elit dayanıklıklık sporcusunun, Bruce protokolü kullanılarak $\mathrm{VO}_{2}$ maks'larının karşılaştırıldığı kesitsel bir araştırmada, omnivorlarla karşılaştırıldığında vejetaryenlerin $\mathrm{VO}_{2}$ maks'larının $(\mathrm{mL} / \mathrm{kg} / \mathrm{min})$ daha fazla olduğu bulunmuştur. Yapılan alt analizlerde bu farklılığın kadın sporculardan kaynaklandığı 
(vejetaryen kadınlarda \% 13 daha fazla) belirtilmiştir. Fakat bu farklılık absolut $\mathrm{VO}_{2}$ maks'ta (L/dk) gözlenmemiştir. Bu çalışmada vejetaryen diyetlerin performans sonuçlarını olumsuz olarak etkilemeyeceği, sporcularda kardiyorespiratuvar fitness sonuçlarını geliştirmek için avantaj olabileceği de belirtilmektedir (Lynch ve ark., 2016).

Sonuç olarak bu çalışmalar doğrultusunda, vegan beslenmenin özellikle kadın sporcularda maksimum oksijen kullanım kapasitesini olumlu yönde etkilediği gözlemlenmiştir. Çalışmalar vegan beslenmeyi, dayanıklılık performansını artırıc1 ya da azaltıcı bir etkiyle ilişkilendirmemiştir (Boutros ve ark., 2020; Leischik ve Spelsberg, 2014; Lynch ve ark., 2016). Sadece veganlarla yapılmış, dayanıklılık performansını ölçen sınırlı çalışma bulunduğundan daha fazla çalışmaya ihtiyaç vardır.

\section{Vegan beslenme ve kuvvet performansi}

Diyet türünün dayanıklılık ve kas gücü performansına etkilerini araştıran, Boutros ve ark. (2020) tarafından yapılan çalışmada, aktif vegan ve omnivor kadınların leg press ve oturarak bench press bir tekrar maksimum kuvvetleri (1-TM) arasında anlamlı bir farklılık bulunmamıştır.

Yirmi yedi vejetaryen (vegan, lakto-ovo vejetaryen) ve 43 omnivor elit dayanıklıklık sporcusunun izokinetik dinomometre ile belirlenen bacak kas ekstansiyonu ve fleksiyonu pik torkları benzer bulunmuştur (Lynch ve ark., 2016).

Powerlifting branşında vücut yağ kütlesinin düşük, YVK'nin yüksek olması istenir. Bir vaka raporunda, genç, profesyonel bir erkek powerlifter sporcusunda, 6 haftalık vegan beslenmenin vücut kompozisyonu üzerine etkileri incelenmiştir. Sporcunun vücut kompozisyonu analizi biyoelektrik impedans analizörü ile gerçekleştirilmiştir. İki fazlı bir diyet programı planlanmıştır. İlk 4 hafta sporcunun diyet içeriği; $2188 \pm 40 \mathrm{kkal}$ veya $34 \mathrm{kkal} / \mathrm{YVK}$ (kg)/gün, 3 $\mathrm{g} / \mathrm{kg} /$ gün karbonhidrat, $2.2 \mathrm{~g} / \mathrm{kg} /$ gün protein veya $2.7 \mathrm{~g} / \mathrm{YVK}(\mathrm{kg}) / \mathrm{gün}$ ve $0.8 \mathrm{~g} / \mathrm{kg} / \mathrm{gün}$ yağ olarak planlanmıştır. İkinci fazda $2730 \pm 50 \mathrm{kkal}$ veya $42 \mathrm{kkal} / \mathrm{YVK}(\mathrm{kg}) / \mathrm{gün}, 4.7 \mathrm{~g} / \mathrm{kg} / \mathrm{gün}$ karbonhidrat, $1.8 \mathrm{~g} / \mathrm{kg} /$ gün protein ve $0.95 \mathrm{~g} / \mathrm{kg} /$ gün yağ olarak uygulanmıştır. Ayrıca, sporcuya dışarıdan soya proteini (proteinin \%76's1), kreatin monohidrat, B 12 vitamini, D vitamini ve $\mathrm{n}-3$ yağ asitleri (deniz yosunu bazlı) gibi bir dizi takviye kullanımı da önerilmiştir. Çalışma süresi sonunda sporcunun 79.3 kg'den 77.4 kg'ye (-\%2.39); yağ kütlesinin 15.0 kg'den 11.4 kg'ye (\%24) düştüğü ve YVK'nin 64.3 kg'den 66.0 kg'ye (+\%2.64) artış gösterdiği görülmüştür. Bu kısa süreli müdahale vücut kompozisyonunu iyileştirmek için tatmin edici bulunmuş ve hiçbir olumsuz sonuç bildirilmemiştir. Ancak vegan beslenme yeterli besin ögeleri sağlama bakımından riskli olabileceği için profesyonel sporculara, kan ve psikolojik testleri içeren uygun sağlık değerlendirmeleri önerilmektedir (Hernández-Martínez ve ark., 2020).

Sonuç olarak bu çalışmalar değerlendirildiğinde, vegan beslenmenin kuvvet performansı üzerine olumlu veya olumsuz bir etkisinin bulunmadığı ancak vücut kompozisyonunu iyileştirebileceği düşünülmektedir (Boutros ve ark., 2020; Hernández-Martínez ve ark., 2020; Lynch ve ark., 2016). Literatürde sadece veganların bulunduğu kuvvet performansını ölçen sınırlı çalışma bulunduğundan daha fazla çalışma yapılmasına ihtiyaç vardır. 


\section{SPORCULARDA VEGAN BESLENME}

\section{Vegan sporcularda diyet ile alınan besin öğelerinin değerlendirilmesi Vegan sporcularda enerji}

Sporcularda enerji harcaması ve alımı arasındaki denge antrenman ve performansı beslenme yoluyla optimize etmenin temel koşuludur (Kerksick ve ark., 2018). Uygun enerji alımı vücut fonksiyonlarını destekler, makro ve mikro besin öğelerinin alım kapasitesini belirler ve vücut kompozisyonunun düzenlenmesine yardımcı olur. Sporcuların günlük enerji ihtiyaçları 40-70 kkal/kg'a yaklaşabilmektedir (Kerksick ve ark., 2018). Fakat sporcuların yaptıkları spor branşına göre enerji ve besin öğesi ihtiyaçları birbirinden farklıdır. Bir sporcunun enerji gereksinmesi dönem içerisinde de farklılıklar göstermektedir. $\mathrm{Bu}$ farklılıklar, antrenman döneminin periyoduna, yarış dönemine, kısaca yıllık antrenman planında oluşturulan yüklenme şiddeti ve kapsamına göre oluşmaktadır(Thomas ve ark., 2016) .Günlük alınan enerji YVK başına 30 kkal'in altına düşmemelidir (Bytomski, 2018).

Vejetaryen ve vegan sporcuların bazıları lif içeriği yüksek, enerji yoğunluğu düşük bitkisel kaynaklı beslenme ile artmış enerji ihtiyacını karşılayamamaktadır (Larson-Meyer, 2018). Ancak iyi dengelenmiş vegan diyetlerin performans sporcularının enerji ihtiyacını karşılamada yeterli olduğu gözlemlenmiştir (Katharina, 2020). Dayanıklılık sporcularının ve estetik sporları (cimnastik, paten, dans vb.) ile ilgilenen sporcuların besin tüketimleri değerlendirildiğinde negatif enerji dengesine yatkın oldukları görülmektedir (Kerksick ve ark., 2018; Rogerson, 2017). Rekreasyonel koşan (haftada 2 ile 5 kez antrenman yapan) 27 omnivor, 25 lakto-ovo vejetaryen ve 27 vegan bireyin besin tüketimlerinin incelendiği kesitsel bir çalışmada gruplar arasında enerji alımında anlamlı bir farklılığa rastlanmamıştır. Ancak her üç grubun yarısından fazlasının önerilen enerji alım miktarına erişemediği gözlemlenmiştir (omnivor grubun \%59.3'ü, lakto-ovo vejetaryen grubun \%52'si ve vegan grubun \%51,9'u) (Nebl ve ark., 2019). Enerji ihtiyacının karşılanamaması menstrual döngünün bozulmasına, kemik sağlığı, psikolojik durum, endokrin, gastrointestinal, kardiyovasküler ve immün sistem üzerine olumsuz etkilere ve büyüme gelişme problemlerine neden olabilir. Ayrica sporcunun performansını olumsuz olarak etkiler, yaralanma ve depresyon görülme riskinde artışa neden olur (Burke ve ark., 2019) .

Antrenman ve performansın en üst seviyede olabilmesi için optimal enerji tüketimi gibi tüketilen enerjinin karbonhidrat, protein ve yăg miktarlarının da yeterli olması bir o kadar önemlidir (Kerksick ve ark., 2018).

\section{Vegan sporcularda makro besin öğeleri \\ Karbonhidrat}

Karbonhidratlar sporcu diyetinde önemli bir yere sahiptir. Karbonhidratların antrenman öncesi alım amacı, kas ve karaciğer glikojen depolarını doldurarak performansı desteklemek ve antrenman sonrası oluşabilecek kas ağrılarını engellemekken, antrenman sonrası tüketim amacı boşalan glikojen depolarını doldurarak toparlanmaya destek olmaktır (Larson-Meyer, 2018; Williams ve Rollo, 2015). Karbonhidrat ihtiyacının belirlenmesinde sporcunun vücut ağırlığı, antrenman/yarışma programları, antrenmanın süre ve şiddeti önemlidir (Thomas ve ark., 2016). Haftada 5-6 kez, günde 2-3 saat, orta şiddette egzersiz yapan sporcularda günlük $5-8 \mathrm{~g} / \mathrm{kg}$ karbonhidrat tüketimi önerilirken, haftada 5-6 kez, günde 3-6 saat şiddetli, günde 1 veya $2 \mathrm{kez}$ antrenman yapan veya orta-yüksek şiddette günde 4-5 saati geçen antrenmanlar yapan sporcularda karbonhidrat önerisi 8-12 g/kg/gün'e kadar çıkabilir (Bytomski, 2018; Kerksick ve ark., 2018). 
Vegan beslenme sebze, meyve, tahıl ve kuru baklagillerden zengin olduğu için diyetin karbonhidrat içeriğinin daha yüksek oranda olması beklenir. Omnivor ve vegan sporcuların karşılaştırıldığ çalışmalarda da vegan sporcular enerjinin \%50-65'ini karbonhidratlardan sağlarken omnivorlarda bu rakamın \%50'den daha az olduğu rapor edilmiştir. Ancak tüketilen yüksek oranda lifli gidaların bir kısmı sindirilemeyen karbonhidratlardan ve ligninden gelmekte, lif oranı fazla olan besinler sindirimi geciktirerek doygunluk hissini arttırmakta, sporcu alması gereken enerji ihtiyacını karşılayamamaktadır. Ayrıca bazı sporcularda lif içeriğinin fazla olması gastrointestinal rahatsızlıklara sebep olabilir (Rogerson, 2017). Bu nedenle enerji ihtiyacının fazla olduğu antrenman günlerinde veya gastrointestinal problem yaşayan sporcularda makarna, pirinç, patates gibi lif içeriği daha düşük karbonhidratlar tercih edilebilir (Schoenfeld, 2020).

\section{Protein}

Vücutta kas protein yıkımı ile kas protein sentezi arasında net protein dengesi olarak adlandırılan bir ilişki vardır (Rogerson, 2017). Sedanter bireylerde nitrojen dengesini korumak için $0.8 \mathrm{~g} / \mathrm{kg} /$ gün protein tüketimi yeterliyken, sporcularda daha fazlasına ihtiyaç bulunmaktadır (Phillips ve van Loon, 2011). Sporcularda öneriler antrenman şiddeti, türü, hedeflenen sportif başarı, enerji gereksinmesi, besin öğelerinin ihtiyacı ve besin seçimlerine göre $1.2-2.0 \mathrm{~g} / \mathrm{kg} / \mathrm{gün}$ aralığında değişmektedir (Thomas ve ark., 2016; Kerksick ve ark., 2018). Uluslararası Atletizm Federasyonları Birliği'nin 2019 yılında yayınladığı konsensüs raporuna göre; stabil ağırlıktaki sporcuların günlük protein ihtiyacı genel popülasyonun protein ihtiyacından fazladır. Ağırlığını korumak veya ağırlık kazanmak isteyen sporcular için öneri $1.3-1.7 \mathrm{~g} / \mathrm{kg} / \mathrm{gün}$, ciddi ağırlık kaybı sürecinde olan sporcular için $2.4 \mathrm{~g} / \mathrm{kg} /$ gün'e kadar çıkabilir. Fakat $2.5 \mathrm{~g} / \mathrm{kg} /$ gün üzerinde protein tüketimi ek bir avantaj sağlamamaktadır (Burke ve ark., 2019).

Vegan sporcuların omnivorlara kıyasla daha düşük miktarda protein tükettiği tespit edilmişse de tüketilen protein miktarının önerilen protein alım aralığına dahil olduğu gözlemlenmiştir (Boutros ve ark., 2020; Brown, 2018; Nebl ve ark., 2019; Schoenfeld, 2020). Sporcularda tüketilen proteinin miktarı kadar kalitesi de önemlidir (Phillips, 2016). Bitkisel kaynaklı proteinler dallı zincirli amino asitler başta olmak üzere, önemli esansiyel amino asitler bakımından genellikle eksiktir. Buğdaydan gelen proteinin, yumurta veya whey protein ile kıyaslandığında kaslardaki akut anabolik cevabı yavaşlattığı görülmüştür (Berrazaga ve ark., 2019). Kas protein sentezini uyaran etkenlerden biri de tüketilen proteinin hizlı sindirilerek kana hızlıca karışmasıdır. Örneğin whey proteini hızlı sindirilen bir proteinken kazein proteini yavaş sindirilen protein grubundadır. Soya proteini de hılı sindirilen protein grubundadır, ancak $10 \mathrm{~g}$ esansiyel amino asit içeren whey proteini ile soya proteini karşılaştırıldığında; soya proteininin, kas protein sentezini whey proteini kadar uyaramadığı gözlemlenmiştir (Lynch ve ark., 2018; van Vliet ve ark., 2015). Bu durumun proteinlerdeki amino asit örüntüsünün farklı olmasından (özellikle düşük löysin miktarı) kaynaklandığı düşünülmektedir (Lynch ve ark., 2018). Bitkisel kaynaklı proteinlerde lizin, metiyonin, izolöysin, treonin ve triptofan aminoasitleri genellikle sınırlayıcı aminoasitledir. Tahıl grubu metiyonin, sistein, triptofan gibi kükürt içeren amino asitler bakımından zenginken, lizin bakımından fakirdir. Baklagiller ise yüksek miktarda lizin, lösin, aspartik asit, glutamik asit ve arjinin içerirken, düşük oranda kükürtlü amino asitleri içermektedir (Çetiner ve Bilek Ersus, 2018; Phillips, 2005). Löysin soya fasulyesi ve mercimekten elde edilebilir. Diğer dallı zincirli amino asitler yağlı tohumlarda ve nohutta bulunabilir. Dolayısıyla, sınırlayıcı olan bu elzem aminoasitler, protein bakımından zengin bitkisel gıdaların farklı kombinasyonları ile çeşitli şekillerde tüketilerek alınabilir (Rogerson, 2017). Ancak hayvansal ve bitkisel kaynaklı proteinlerin bir diğer farkı da proteinin sindirilebilirliğini etkileyen antinutrisyonel faktörlerdir. Bitkisel kaynaklı proteinlerde doğal 
olarak daha fazla oranda antinutrisyonel olarak sınıflandırılan glikozit, tripsin inhibitörleri, hemaglutinin, tanin ve fitatlar bulunmaktadır. Bu faktörlerin her biri farklı metabolik yolaklar ile tüketilen proteinin sindirilebilirliğini azaltır (Gilani ve ark., 2005). Fakat, 1slatma, fermantasyon ve çimlenme gibi çeşitli hazırlama teknikleriyle antinutrisyonel faktörlerden fitatın miktarı azaltılabilir (Gilani ve ark., 2005). Sonuç olarak bitkisel kaynaklı proteinlerdeki sınırlı elzem aminoasit örüntüsü ve antinutrisyonel faktörlere rağmen besinlerin çeşitli ve dengeli olarak tüketilmesiyle vegan diyet yeterli miktarda esansiyel aminoasit sağlayabilir (Thomas ve ark., 2016; Lynch ve ark., 2018).

Diyette hiçbir hayvansal kaynaklı proteinin bulunmaması nedeniyle, vegan sporcuların 1.4- 2.0 $\mathrm{g} / \mathrm{kg} / \mathrm{gün}$ proteinden daha fazla alması düşünülebilir. Bitkisel kaynaklı proteinlerin kalitesinin düşük olması nedeniyle ağırlık kaybetme aşamalarında 1.8-2.7 g/kg/gün alımı uygun olabilir (Rogerson, 2017).

\section{Yă}

Vücuda enerji sağlarken, hücre zarının temel yapısını oluşturmada ve yağda çözünen vitaminlerin emilimini kolaylaştırmada katkı sağladığından, yağ sağlıklı bir diyetin önemli bir bileşenidir (Thomas ve ark. 2016). Sporcunun antrenman durumuna veya hedeflerine göre günlük diyetle önerilen yağ alım miktarı değişse de, genel olarak $0.5-1.0 \mathrm{~g} / \mathrm{kg}$ ve $/ \mathrm{veya}$ enerjinin \% 30'unun yağlardan karşılanması önerilir (Kerksick ve ark., 2018; Kerksick ve Kulovitz, 2013). Vücut yağ kütlesini azaltmak isteyen sporcular için güvenli alım miktarı günlük toplam enerjinin \% 20'sine kadar düşmektedir, \% 20'nin altındaki alım diyet çeşitliliğinde azalma ve yağda çözünen vitaminler ile özellikle başta n-3 yağ asidi olmak üzere esansiyel yağ asitlerinin alımının sınırlanması ile ilişkilidir (Thomas ve ark., 2016; Kerksick ve ark., 2018).

Vegan sporcular için öneri $0.5-1.5 \mathrm{~g} / \mathrm{kg} /$ gün (veya toplam enerjinin \% 30’u) aralığındadır (Rogerson, 2017). Tüketilen yağın sağlığa olan etkileri üzerinde miktar kadar yağ asidi kompozisyonu da önemlidir (Mensink, 2005). Amerikalılar için Diyet Yönergesi (2015-2020), Kanada Beslenme Rehberi (2019) ve Türkiye Beslenme Rehberi (2015)'nin önerilerine göre günlük alınması gereken enerjinin doymuş yağlardan gelen oranının \% 10'u geçmemesi tavsiye edilirken diyette önerilen yeterli alım (AI) miktarını karşılayabilmek için esansiyel yağ asitlerinin diyete eklenmesinin önemi vurgulanmıştır ( T.C. Sağlık Bakanlığı, 2016; Health Canada, 2019; Slavin, 2012). Volek ve ark. (1997), düşük yağlı diyetin erkeklerde testosteron seviyesini olumsuz etkileyebileceğini, vejetaryenlerin omnivorlara göre testosteron seviyelerinin daha düşük olduğunu belirtmiştir. Omnivor erkekler ile toplam yağ ve doymuş yağ alımı düşük olan vegan erkeklerin androjen seviyelerinin karşılaştırıldığı çalışmaları inceleyen bir derlemede vegan ve omnivor erkeklerin androjen seviyelerinde farklılığa rastlanmamıştır (Simopoulos, 2007).

Vegan diyetler omnivor diyetlere göre daha az yağ ve doymuş yağ içermekte (Clarys ve ark., 2014; Phillips, 2005; Sakkas ve ark., 2020), veganların omnivorlara göre n-6 yağ asidini daha fazla, tekli doymamış yağ asitlerini daha az aldıkları belirtilmektedir (Clarys ve ark., 2014; Davey ve ark., 2003; Rosell ve ark., 2005). Ayrıca vegan beslenmede deniz ürünlerine yer verilmediği için veganların n-3 yağ asidi tüketimleri daha az ve serum n-3 yağ asidi seviyeleri de daha düşüktür (Rogerson, 2017). Vegan, vejetaryen ve omnivor koşucuların beslenme alışkanlıklarının ve besin tüketimlerinin karşılaştırıldığı bir çalışmada, vegan sporcuların omnivor ve vejetaryen sporculara göre daha az miktarda toplam yăg ve doymuş yağ tükettikleri, daha az oranda tekli doymamış yağ asitleri aldıkları belirtilmiş, çoklu doymamış yağ asitlerinin alım miktarları bakımından anlamlı bir farklılık bulunmamıştır (Nebl ve ark., 2019). n-3 yă asidi ile ilgili, vegan beslenme özelinde detaylandırma yapılmamışsa da sporcular için günlük 
EPA ve DHA toplam alım miktarı 1-2 g, alım oranı ise 2:1 olarak önerilmektedir (Simopoulos, 2007). Bitkisel kaynaklı n-3'ten zengin besinler; chia tohumu, chia tohumu yağı, keten tohumu, keten tohumu yağı, kanola yağı, ceviz, ceviz yağı, kenevir tohumu, kenevir tohumu yağı, soya fasulyesi, soya fasulyesi yağı, buğday tohumu, buğday tohumu yağı ve yeşil yapraklı sebzeler, mikroalgler (mavi- yeşil algler değil), deniz otudur (Saunders ve ark., 2013).

\section{Vegan sporcularda mikro besin öğeleri}

Vitaminler ve mineraller fiziksel performans için önemli olan çeşitli metabolik süreçlerde yer alır (Nebl ve ark., 2019). Bitkisel kaynaklı beslenmenin sporcular için gerekli besin öğelerini sağlayıp sağlayamayacağı halen tartışma konusu olsa da bazı beslenme birlikleri, çeşitliliği zengin bitkisel ürünleri barındıran iyi düzenlenmiş vejetaryen diyet örüntüsünün sporcuların gereksinmesini karşılayabileceğini düşünmektedir (Nebl ve ark., 2019). Yağsız kırmızı et, balık ve yumurta gibi hayvansal kaynaklı besinler $\mathrm{B}_{12}$ vitamini ve biyoyararlanımı yüksek çinko, demir ve D vitamini gibi mikro besin öğeleri için iyi kaynaklardır (Iannotti ve ark., 2014; McAfee ve ark., 2010; Nebl, Schuchardt, Ströhle ve ark., 2019). Beslenme ve Diyetetik Akademisi özellikle vegan diyetlerde $\mathrm{B}_{12}$ vitamini, demir, çinko, kalsiyum, iyot ve D vitamininin yeterli tüketimine dikkat çekmektedir (Cullum-Dugan ve Pawlak, 2015).

\section{B12 Vitamini (Kobalamin)}

Eritropoez, miyelin kılıfının sentezi ve onarımı, nükleik asit (DNA) sentezinde görevleri olan $\mathrm{B}_{12}$ vitamininin doğal kaynağı et ve hayvansal ürünlerdir (Pawlak ve ark., 2014). Watanabe ve ark. (2014), yenilebilir bazı yabani mantarlar, tempeh (fermente edilmiş soya fasulyesi) ve kurutulmuş mor deniz yosunu (nori) gibi bazı bitkisel ürünlerde de $\mathrm{B}_{12}$ vitamini olduğunu ancak $\mathrm{B}_{12}$ vitamininin bitkisel kaynaklarının insanlardaki biyoyararlanım ve yeterliliği konusunun netlik kazanmadığını belirtmişlerdir ( Larson-Meyer, 2019) .

Veganlarda önerilen tüketim miktarına ulaşılamadığı için $\mathrm{B}_{12}$ vitamini eksikliği riski bulunmaktadır (Pawlak ve ark., 2014). Sporcular üzerinde yapılmış araştırmalarda, vegan beslenen sporcuların omnivor beslenenlere göre diyetlerinde anlamlı miktarda daha az $\mathrm{B}_{12}$ vitamini aldığı tespit edilmiştir (Nebl ve ark., 2019; Nebl ve ark., 2019b; Wirnitzer ve ark., 2019).

Günlük önerilen $B_{12}$ vitamini alım miktarı hem sporcular hem sedanter bireyler için 2.4 mcg'dır ( Larson-Meyer, 2019). Veganlarda hayvansal kaynaklı gıda tüketimi olmadığı için, B12'den zenginleştirilmiş besinlerin günlük diyette düzenli bir şekilde tüketimi ya da hekim kontrolünde düzenli takviye kullanımı önerilmektedir (Brown, 2018; Craig ve Mangels, 2009; Fuhrman ve Ferreri, 2010; Larson-Meyer, 2018; Rogerson, 2017; Schoenfeld, 2020). B 12 vitamininin en güvenilir ve yaygın formu siyanokobalamindir (Heller, 2019). $\mathrm{B}_{12}$ vitamin gereksinimini karşılamak için 3 öneri bulunmaktadır: 1) Her biri en az 2-3.5 mcg $\mathrm{B}_{12}$ vitamini ile zenginleştirilmiş besin olmak üzere günde 2 porsiyon tüketilmelidir. Besinlerin optimal emilimi için ögünler arasında en az 4 saat ara olmalıdır. 2) Günlük 25-100 mcg veya 3) Haftada iki kez 1000 mcg B 12 vitamini desteği yapılmalıdır (Heller, 2019).

$\mathrm{B}_{12}$ vitamininden zengin bitkisel kaynaklı besinler; besin mayası, zenginleştirilmiş soya sütü (markaya göre değişir), zenginleştirilmiş kahvaltılık gevrekler, tempeh, mor deniz yosunu (nori), şitake mantarıdır (Heller, 2019; Watanabe ve ark., 2014). 


\section{Demir}

Demir, hemoglobin ve miyoglobinin oluşumu, protein metabolizması, mitokondrinin doğru çalışması gibi süreçlerde yer alır ve bazı enzimatik olaylarda kofaktör olarak görev yapar. Vücut için önemli ve esansiyel bir besin öğesidir (Brown, 2018).

Bir derlemede tam tahıl ve baklagillerden zengin bitkisel kaynaklı beslenenler ile omnivorların benzer miktarda demir aldığı belirtilmiştir (Rogerson, 2017). Hatta yapılan derlemelerde ve bir çalışmada veganların demir alımının daha yüksek olduğu bildirilmiştir (Craig, 2009; Fuhrman ve Ferreri, 2010; Nebl ve ark., 2019). Ancak diyet ile alınan demirin iki formu bulunmaktadır. Hayvansal kaynaklı besinlerde hem demir, bitkisel kaynaklı besinlerde non-hem demir bulunur. Kimyasal farklılıklardan dolayı, hem demir vücutta \% 15- 40, non-hem demir yaklaşık \% 1-15 oranında emilir (Hunt, 2002). Vücudun depo demir durumu iki demir türünün emilimini etkilese de non-hem demirin emilimi hem demire göre depo demirin durumundan daha fazla etkilenir. Vücuttaki demir depoları düşükse non-hem demir hem demire göre daha iyi absorbe edilir. Askorbik asit ve diğer organik asitler demir emilimini artırırken, fitat ve tanen gibi bileşenler azaltır. Dolayısıyla vegan diyetlerin hem demir içermemesi, fazla miktarda fitat ve lif içermesinden dolayı alınan demirin biyoyararlılığı değerlendirilmelidir (Waldmann ve ark., 2004). Bu nedenle, erkekler için $8 \mathrm{mg} /$ gün, kadınlar için $18 \mathrm{mg} /$ gün olan demir alım miktarının, vejetaryenler için \% 80 oranında artırılarak erkeklerde $14 \mathrm{mg}$ gün, kadınlarda $33 \mathrm{mg} / \mathrm{gün}$ olması önerilmektedir (Rogerson, 2017). Sporcularda antrenman programları ile daha fazla demir kaybı görülmesi nedeniyle bu öneriler vejetaryen sporcular için artmaktadır (Zhou ve ark., 2014).

Demirden zengin bitkisel kaynaklı besinler; 1spanak, pazı, kuşkonmaz, brokoli, lahana, tofu, tempeh, soya sütü, soya fasulyesi, mercimek, yulaf ezmesi, kabak çekirdeği, susam, badem, antep fistığı, kuru incir, kuru üzüm, zenginleştirilmiş kahvaltılık gevreklerdir (Fuhrman ve Ferreri, 2010; Norris, 2012).

\section{Çinko}

Çinko, DNA stabilizasyonu ve gen ekspresyonu ile ilgili metabolik süreçlerde yer alan enzimlerin yapısına katılır. Bu nedenle hücre büyümesi, onarımı ve protein metabolizmasında önemli bir mikro elementtir (Rogerson, 2017). Demir gibi bitkisel kaynaklarda yaygın olarak bulunmasına rağmen, bitkisel kaynakların fitatlardan zengin olması nedeniyle emilimi düşüktür. Çinko alımı yetersiz olduğunda vücudun adaptasyon olarak kayıpları azalttığı ve emilimi artırdığı bilinmektedir (Marsh ve ark., 2012). Sağlıklı bireyler için günlük alım önerileri erkekler için $11 \mathrm{mg}$, kadınlar için $8 \mathrm{mg}$ 'dır. Ancak hem sedanter hem sporcu veganlarda tüketilen çinkonun biyoyararlılığının düşük olması nedeniyle erkekler için 16.5 mg/gün, kadınlar için $12 \mathrm{mg}$ /gün alım önerilmekle beraber (Fuhrman ve Ferreri, 2010) sporcuların antrenman nedenli terleme ve idrar ile artan çinko kayıpları da unutulmamalıdır (Zhou ve ark., 2014).

Çinkodan zengin bitkisel kaynaklı besinler; nohut, badem, yulaf ezmesi, soya sütü, zenginleştirilmiş mısır gevrekleri, tempeh, ay çekirdeği, kabak çekirdeğidir (Heller, 2019).

\section{Kalsiyum}

Kalsiyum, özellikle kemik dokusunun gelişimi, korunması ve onarımında, kas kasılmasının düzenlenmesinde, sinir iletimi ve normal kan pıhtılaşmasında önemli göreve sahiptir (Thomas ve ark., 2016). Özellikle ağırlık kaldıran (halter gibi branşlar) ve/veya enerji alımı yetersiz olan sporcularda diyetle kalsiyum alımının düşük olması kas iskelet problemlerine neden olabilir (Rogerson, 2017). Önerilen günlük kalsiyum alımı yaşa göre değişmektedir; 9-18 yaş için 1300 
mg, 19-50 yaş için $1000 \mathrm{mg}, 50$ yaş üstü yetişkinler için $1200 \mathrm{mg}$, menopoz sonrası kadınlar için ise $1500 \mathrm{mg}$ olup bu öneriler vegan sporcular için de aynıdır. Ancak amenoresi olan kadın sporcularda kalsiyum ihtiyacı artar ve günlük 1500 mg/gün önerilir (Kunstel, 2005).

Kalsiyum alımı veganlarda, omnivor ve vejetaryenlere göre anlamlı miktarda düşük olduğu için kemik sağlı̆̆ının riskli olduğu görülmüş ve yapılmış geniş çaplı kohort çalışmada kırık riskinin omnivorlara göre veganlarda \%30 daha fazla olduğu raporlanmıştır (Appleby ve ark., 2007). Ayrıca kemik mineral yoğunluğunun da veganlarda daha düşük oranda olduğu görülmüş ancak klinik olarak bu fark anlamlı bulunmamıştır (Ho-Pham ve ark., 2009). Sporcular üzerinde yapılan çalışmalarda, genellikle vegan sporcuların kalsiyum tüketiminin daha düşük olduğu gözlemlense de (Nebl, Haufe, Eigendorf, ve ark. 2019; Nebl, Schuchardt, Wasserfurth, ve ark. 2019), 22 vegan 35 omnivor dayanıklılık sporcusunun performanslarının karşılaştırıldığı bir çalışmada vegan sporcuların daha yüksek miktarda kalsiyum aldıkları raporlanmış, fakat çalışmada kalsiyumun biyoyararlılığı değerlendirilmemiş ve gruplar arasındaki fark önemli bulunmamıştır (Lynch ve ark., 2016).

Kalsiyumdan zengin bitkisel kaynaklı besinler; brokoli, lahana, kara lahana, hardal otu, bamya, yeşil yapraklı sebzeler (1spanak dışında), soya sütü, pirinç sütü ve yulaf sütü gibi zenginleştirilmiş bitkisel sütler, kuru üzüm, kuru erik, kuru kayısı ve kuru incir gibi bazı kuru meyveler, tofu, tempeh, susam, tahin, bezelye ve mercimektir (Hsu, 2020).

\section{İyot}

İyot, tiroid fonksiyonu ve metabolizmasında görev alan, hem mental hem fiziksel gelişim için önemli rol oynayan bir eser elementtir (Rogerson, 2017). Önerilen alım miktar1 $150 \mu \mathrm{g} /$ gün'dür. Deniz yosunu veya iyot takviyesi içermeyen vegan diyetlerde önerilen miktarın altında iyot alımının olduğu ve önerilen tüketim miktarına erişemeyen bireylerde iyot yetersizliği hastalıklarının görülme riskinin arttığı bilinmektedir (Eveleigh ve ark., 2020).

Veganlarda süt, süt ürünleri, balık ve yumurtanın tüketilmemesi ve zenginleştirilmiş birkaç bitkisel süt hariç bitkisel sütlerin genellikle çok düşük miktarda iyot içermesi nedeniyle iyot alımı yetersiz kalabilmektedir (Brantsæter ve ark., 2018; Groufh-Jacobsen ve ark., 2020). Sporcularda veya yoğun egzersiz yapan bireylerde sıcaklık ve nem gibi çevresel faktörlere bağlı olarak terleme yoluyla önemli miktarda iyot kaybı olabilir. Sürekli iyot kaybı tiroid fonksiyonlarını ve dolayısıyla sportif performansı etkileyebilir (Read ve Grundy, 2012).

İyottan zengin bitkisel kaynaklı besinler; zenginleştirilmiş sofra tuzu, deniz yosunu, iyot takviyesidir (Brantsæter ve ark., 2018; Heller, 2019).

\section{D vitamini}

D vitamini, kalsiyum ve fosforun emilimini ve metabolizmasını düzenleyerek kemik sağlığının korunmasında önemli bir görev almaktadır (Thomas ve ark., 2016). Son yıllarda yeterli D vitamini alımının sportif performans üzerine olan etkisi dikkat çekmektedir. Yeterli D vitamini seviyesi ile kas protein sentezi, ATP konsantrasyonu, kas kuvveti, sıçrama yüksekliği, hızı, gücü, egzersiz kapasitesi ve fiziksel performans arasında pozitif ilişki olduğu, yeterli D vitamini düzeyinin inflamasyon, ağrı ve miyopatiyi azalttı̆̆ı düşünülmektedir (Shuler ve ark., 2012).

D vitamini mekanizması gereği hormona benzemekte ve doğru miktarda güneşe maruz kalma ile ciltte ihtiyaç kadar üretilmektedir. Ancak üretilen miktar, günün saati, mevsim, enlem, cilt pigmentasyonu, güneş kremi kullanım durumu, maruz kalan cilt yüzey miktarı, maruz kalma süresi ve yaş gibi birçok faktöre bağlıdır (Marsh ve ark., 2012). Sporcular için D vitamini 
alımlarının bireysel olarak değerlendirilmesi ve güneş ışı̆̆ına maruz kalma süresi (vücudun veya kolların ve bacakların \%35'i) günde $<20 \mathrm{dk}$ ile sınırlı olan, $<30^{\circ}$ veya $>60^{\circ}$ enlemlerinde yaşayan ve ayrıca serum kalsidiol $(25(\mathrm{OH}) \mathrm{D})$ düzeyi $75 \mathrm{nmol} / \mathrm{L}$ 'nin altında olan sporcuların günlük 2.000- 4.000 IU D3 vitamini alması önerilmektedir (Owens ve Close, 2013). Serum 25 $(\mathrm{OH})$ D'nin ölçülmesi, hem ultraviyole (UV) B radyasyonuna maruz kalmayı hem de diyet ile alınan D vitamini durumunu yansıttığı için D vitamini durumunu değerlendirmede klinik bir standarttır (Farrokhyar ve ark., 2015).

Derleme bir çalışmada, sporcuların \%56'sında coğrafi konuma göre önemli ölçüde değişen D vitamini yetersizliği (serum $25(\mathrm{OH}) \mathrm{D}<32 \mathrm{ng} / \mathrm{mL}$ ) olduğu belirtilmiştir (Farrokhyar ve ark., 2015). Yapılan çalışmalarda vegan sporcularda omnivorlara göre daha düşük miktarda D vitamini alımı gözlemlense de bu fark bazı çalışmalarda anlamlı bulunmamıştır (Lynch ve ark., 2016; Nebl ve ark., 2019).

D vitamininden zengin bitkisel kaynaklı besinler; zenginleştirilmiş soya sütü, zenginleştirilmiş portakal suyu, zenginleştirilmiş soya yoğurdu, ıgara portebello mantarı, zenginleştirilmiş badem sütü, zenginleştirilmiş mısır gevrekleridir (Heller, 2019) .

\section{Vegan sporcularda kreatin-karnitin-beta alanin ve taurin \\ Kreatin}

Kreatin, arginin, glisin ve metioninden endojen olarak sentezlenen azotlu, organik bir asittir (Rogerson, 2017). Kısa süreli, yoğun egzersiz sırasındaki yorgunluğun, kastaki fosfokreatinin (PCr) tükenmesi ile ilişkili olduğu bilinmektedir (Sahlin ve ark., 1998). Bu nedenle kastaki PCr'nin artmasıyla maksimum kuvvet performansının arttığı düşünülmektedir. PCr, kreatinin fosforilasyonu ile üretildiğinden, kas kreatininin artması ile PCr artar ve performansta artış beklenir (Shomrat ve ark., 2000). Aralarında veganların da bulunduğu vejetaryen ve omnivorların kreatin seviyesinin değerlendirildiği ve ağırlık antrenmanının kas kreatin seviyesine ve performansa etkilerinin incelendiği bir çalışmada, omnivorlora göre vejetaryenlerin toplam kreatin seviyelerinin daha düşük olduğu gösterilmiştir (Burke ve ark., 2003). Et, balık ve kümes hayvanları gibi yiyecekler zengin kreatin kaynaklarıdır (Rogerson, 2017).

Vegan sporcular, sentetik kreatinin toz formlarını tüketebilir (kapsüllü ürünler sığır jelatini içerebilir). Kreatin depolanmasını sağlamanın en optimal yolu, takviye kreatinin bir protein ve karbonhidrat karışımı ile birlikte alınmasıdır (Rogerson, 2017).

\section{Karnitin}

Karnitin, karaciğer ve böbrekler tarafından endojen olarak üretilen (Kerksick ve ark., 2018) ve uzun zincirli yağ asitlerini oksidasyon için mitokondriye taşıyan bir moleküldür (Jäger ve ark., 2017). Vücut karnitininin \%95'inden fazlası, enerji metabolizması için gerekli olan iskelet kasında bulunur (Novakova ve ark., 2016). Karnitinin fazla bulunmasının yağ oksidasyonunu artırdı ğına dair kanıtlar eksik olsa da karnitin ile kas glikojeninin korunması ve egzersize bağlı kas hasarında azalma ilişkilidir (Jäger ve ark., 2017).

Karnitin et ve süt ürünlerinde bulunur, bitkisel gıdalarda bulunmaz. Omnivorlara göre vejetaryenlerde kan karnitin konsantrasyonlarının daha düşük olduğu bulunmuştur (LarsonMeyer, 2019). Aralarında veganların da bulunduğu vejetaryen ve omnivor erkeklerin vücut karnitin havuzu, iskelet kas enerji metabolizması ve fiziksel performansının değerlendirildiği bir çalışmada, omnivorlara kıyasla vejetaryenlerin plazma karnitin konsantrasyonlarının daha düşük olduğu, kas karnitin depolarında anlamlı bir farklılık bulunmadığı belirtilmiştir. Ayrıca 
vejetaryen grupta oral olarak alınan L-karnitin takviyesinin plazma karnitin konsantrasyonunun normal seviyelerine gelmesini sağladığı, kas konsantrasyonunu iyileştirdiği fakat kas fonksiyonunu ve enerji metabolizmasını etkilemediği raporlanmıştır (Novakova ve ark., 2016)

\section{Beta- alanin}

Beta- alanin karaciğerde endojen olarak üretilen, esansiyel olmayan bir amino asittir. Karnozin sentezindeki rolüne bağlı olarak ergojenik potansiyele sahiptir (Trexler ve ark., 2015). Karnozin iskelet kasında doğal olarak fazla miktarda bulunan, histidin ve beta-alanin amino asitlerinin birleşmesiyle oluşmuş bir dipeptittir. Karnozinin iskelet kaslarında tamponlama kapasitesi üzerinde olduğu bilinmektedir (Kerksick ve ark., 2018).

Derleme bir çalışmada, vejeteryanların omnivorlara kıyasla daha düşük kas karnozin seviyelerine sahip olduğu belirtilmektedir (Harris ve ark., 2012). Aralarında veganların da bulunduğu bir çalışmada, uzun dönem beta-alanin kısıtlı beslenmenin kas içi karnozin seviyelerinde düşüş ile ilişkili olduğu bulunmuştur (Everaert ve ark., 2011).

Beta-alanin doğal olarak et, balık ve kümes hayvanlarının yanı sıra bitkisel yağlarda eser miktarlarda bulunmaktadır. Veganlarla ilgili net öneriler olmasa da, yüksek yoğunluklu antrenman yapan vejeteryan sporcuların diyetleri planlanırken beta-alanin alımlarına dikkat etmeleri önerilmektedir (Zhou ve ark., 2014).

\section{Taurin}

Taurin, insanlarda safra asidi konjugasyonu, kardiyovasküler fonksiyon, nörotransmisyon ve öglisemi dahil olmak üzere birçok önemli fizyolojik süreçte rol oynayan kükürtlü bir amino asittir (Rogerson, 2017). Taurin eksikliği kas gelişimini, yapısını ve fonksiyonunu bozabilir (Spriet ve Whitfield, 2015). Taurin, deniz ürünleri, et ve süt ürünlerinde bulunur (Rogerson, 2017) Veganlar ile yapılan bir çalışmada uzun süreli taurinden kısıtlı beslenmenin plazma taurin seviyesini düşürdüğü raporlanmıştır (Laidlaw ve ark., 1988).

Vegan beslenmede taurin kaynağı bulunmaması nedeniyle veganların taurin takviyelerinden yararlanması önerilmektedir (Rogerson, 2017).

\section{SONUÇ}

Genel olarak vegan diyetler omnivor diyetlere göre daha düşük miktarda enerji, protein, yağ, $\mathrm{B}_{12}$ vitamini, n-3 yağ asidi, kalsiyum ve iyot; daha yüksek miktarda ise karbonhidrat, lif, mikro besin öğeleri, fitokimyasallar ve antioksidanlar içermektedir. Günümüzde vegan beslenme oldukça popüler ve güncel bir konudur. Sağlık üzerine olan olumlu etkilerinin yanı sıra iyi düzenlenmemiş vegan bir diyet ile günlük besin öğesi ihtiyaçlarının eksik kalabileceği, sağlık için olumsuz etkilerinin olabileceği unutulmamalıdır.

Şu ana kadar yapılan çalışmalardan yola çıkarak vegan diyetlerin sportif performansı arttırdığına dair kesin kanıtlar bulunmamaktadır. Omnivor ve vegan sporcuların karşılaştırıldığı çalışmalarda gözlemlenen birkaç farklılık dışında vegan beslenmenin performans üzerinde olumlu ya da olumsuz bir etkisi bulunmamıştır. Katılımcı sayılarının az olması, vegan diyet uygulama sürelerindeki farklılıklar, özellikle kuvvet performansı ve branşa özgü performans üzerine etkilerle ilgili az sayıda çalışma bulunması gibi nedenlerle literatürdeki bilgiler sınırlıdır. Vegan sporcuların sağlığını korumak ve performanslarını geliştirmek, enerji ihtiyacı, makro ve mikro besin öğesi gereksinimlerini belirlemek amacıyla daha fazla çalışma yapılmasına ihtiyaç bulunmaktadır. 
Vegan sporcuların beslenme durumunun saptanması, sağl1k kontrollerinin yapılması; negatif enerji dengesinin oluşmaması ve özellikle vegan beslenme ile yeterli miktarda alınamayan $\mathrm{B}_{12}$ vitamini, D vitamini, protein, n-3 yağ asidi, kalsiyum, demir, çinko, iyot, karnitin, kreatin gibi öğelerin gerekli ise dişarıdan takviye olarak verilmesi ve takibinin yapılması açısından önemlidir. Bu besin öğelerinin yetersiz alınmasına bağlı olarak; kas gücü ve kas kütlesinde düşüş, aerobik ve anaerobik performansta azalma, düşük kemik mineral yoğunluğu, stres kırıkları, sakatlanmalarda artış, hastalıklara karşı direncin azalması, oksijen alımının azalması, laktat birikiminde artış, kas yorgunluğu, toparlanmanın gecikmesi, büyüme ve gelişme problemleri gibi sporcunun hem performansını hem de sağlığını etkileyecek problemlerin oluşabileceği unutulmamalıdır. Bu nedenle vegan sporcunun beslenmesi konunun uzmanı bir spor diyetisyeni tarafından takip edilmeli, iyi planlanmış bir beslenme programı uygulanmalidir.

\section{KAYNAKLAR}

Agnoli, C., Baroni, L., Bertini, I., Ciappellano, S., Fabbri, A., Papa, M., ... Sieri, S. (2017). Position paper on vegetarian diets from the working group of the Italian Society of Human Nutrition. Nutrition, Metabolism and Cardiovascular Diseases, 27(12), 1037-1052.

Appleby, P., Roddam, A., Allen, N., Key, T. (2007). Comparative fracture risk in vegetarians and nonvegetarians in EPIC-Oxford. European journal of clinical nutrition, 61(12), 1400-1406.

Appleby, P. N., Key, T. J. (2016). The long-term health of vegetarians and vegans. Proceedings of the Nutrition Society, 75(3), 287-293.

Barnard, N. D., Cohen, J., Jenkins, D. J., Turner-McGrievy, G., Gloede, L., Jaster, B., ..., Talpers, S. (2006). A low-fat vegan diet improves glycemic control and cardiovascular risk factors in a randomized clinical trial in individuals with type 2 diabetes. Diabetes care, 29(8), 1777-1783.

Barnard, N. D., Goldman, D. M., Loomis, J. F., Kahleova, H., Levin, S. M., Neabore, S., Batts, T. C. (2019). Plantbased diets for cardiovascular safety and performance in endurance sports. Nutrients, 11(1), 130.

Benatar, J. R., Stewart, R. A. (2018). Cardiometabolic risk factors in vegans; A meta-analysis of observational studies. PloS one, 13(12), e0209086.

Berrazaga, I., Micard, V., Gueugneau, M., Walrand, S. (2019). The role of the anabolic properties of plant-versus animal-based protein sources in supporting muscle mass maintenance: a critical review. Nutrients, $11(8), 1825$.

Boutros, G. H., Landry-Duval, M. A., Garzon, M., Karelis, A. D. (2020). Is a vegan diet detrimental to endurance and muscle strength?. European journal of clinical nutrition, 74(11), 1550-1555.

Brantsæter, A. L., Knutsen, H. K., Johansen, N. C., Nyheim, K. A., Erlund, I., Meltzer, H. M., Henjum, S. (2018). Inadequate iodine intake in population groups defined by age, life stage and vegetarian dietary practice in a norwegian convenience sample. Nutrients, 10(2), 230.

Brown, D. D. (2018). Nutritional considerations for the vegetarian and vegan dancer. Journal of Dance Medicine \& Science, 22(1), 44-53.

Burke, D. G., Chilibeck, P. D., Parise, G. I. A. N. N. I., Candow, D. G., Mahoney, D. O. U. G. L. A. S., Tarnopolsky, M. (2003). Effect of creatine and weight training on muscle creatine and performance in vegetarians. Medicine \& Science in Sports \& Exercise, 35(11), 1946-1955.

Burke, L. M., Castell, L. M., Casa, D. J., Close, G. L., Costa, R. J., Desbrow, B., ... Stellingwerff, T. (2019). International association of athletics federations consensus statement 2019: nutrition for athletics. International Journal of Sport Nutrition and Exercise Metabolism, 29(2), 73-84. 
Bytomski, J. R. (2018). Fueling for performance. Sports health, 10(1), 47-53.

Carr, A. J., Hopkins, W. G., Gore, C. J. (2011). Effects of acute alkalosis and acidosis on performance. Sports medicine, 41(10), 801-814.

ÇETINNER, M.,BİLEK, S. E. (2018). Bitkisel protein kaynakları. Çukurova Tarım ve Gıda Bilimleri Dergisi, 33(2), $111-126$

Cialdella-Kam, L., Kulpins, D., Manore, M. M. (2016). Vegetarian, gluten-free, and energy restricted diets in female athletes. Sports, 4(4), 50.

Clarys, P., Deliens, T., Huybrechts, I., Deriemaeker, P., Vanaelst, B., De Keyzer, W., ...Mullie, P. (2014). Comparison of nutritional quality of the vegan, vegetarian, semi-vegetarian, pesco-vegetarian and omnivorous diet. Nutrients, 6(3), 1318-1332.

Craddock, J. C., Neale, E. P., Peoples, G. E., Probst, Y. C. (2020). Plant-based eating patterns and endurance performance: A focus on inflammation, oxidative stress and immune responses. Nutrition Bulletin, 45(2), 123132.

Craddock, J. C., Probst, Y. C.,Peoples, G. E. (2016). Vegetarian and omnivorous nutrition-Comparing physical performance. International journal of sport nutrition and exercise metabolism, 26(3), 212-220.

Craig, W. J. (2009). Health effects of vegan diets. The American journal of clinical nutrition, 89(5), 1627S-1633S.

Craig, W. J.,Mangels, A. R. (2009). Position of the American Dietetic Association: vegetarian diets. Journal of the American dietetic association, 109(7), 1266.

Cramer, H., Kessler, C. S., Sundberg, T., Leach, M. J., Schumann, D., Adams, J.,Lauche, R. (2017). Characteristics of Americans choosing vegetarian and vegan diets for health reasons. Journal of nutrition education and behavior, 49(7), 561-567.

Crowe, F. L., Steur, M., Allen, N. E., Appleby, P. N., Travis, R. C.,Key, T. J. (2011). Plasma concentrations of 25-hydroxyvitamin D in meat eaters, fish eaters, vegetarians and vegans: results from the EPIC-Oxford study. Public health nutrition, 14(2), 340-346.

Cui, X., Wang, B., Wu, Y., Xie, L., Xun, P., Tang, Q., ...Shen, X. (2019). Vegetarians have a lower fasting insulin level and higher insulin sensitivity than matched omnivores: A cross-sectional study. Nutrition, Metabolism and Cardiovascular Diseases, 29(5), 467-473.

Cullum-Dugan, D.,Pawlak, R. (2015). Removed: position of the academy of nutrition and dietetics: vegetarian diets. Journal of the Academy of Nutrition and Dietetics, 115(5), 801-810.

Davey, G. K., Spencer, E. A., Appleby, P. N., Allen, N. E., Knox, K. H.,Key, T. J. (2003). EPIC-Oxford: lifestyle characteristics and nutrient intakes in a cohort of 33883 meat-eaters and 31546 non meat-eaters in the UK. Public health nutrition, 6(3), 259-268.

Deriemaeker, P., Aerenhouts, D., Hebbelinck, M.,Clarys, P. (2010). Nutrient based estimation of acid-base balance in vegetarians and non-vegetarians. Plant foods for human nutrition, 65(1), 77-82.

Devrim-Lanpir, A., Hill, L.,Knechtle, B. (2021). Efficacy of popular diets applied by endurance athletes on sports performance: beneficial or detrimental? A narrative review. Nutrients, 13(2), 491.

Dinu, M., Abbate, R., Gensini, G. F., Casini, A., Sofi, F. (2017). Vegetarian, vegan diets and multiple health outcomes: a systematic review with meta-analysis of observational studies. Critical reviews in food science and nutrition, 57(17), 3640-3649.

Eveleigh, E. R., Coneyworth, L. J., Avery, A.,Welham, S. J. (2020). Vegans, Vegetarians, and Omnivores: How Does Dietary Choice Influence Iodine Intake? A Systematic Review. Nutrients, 12(6), 1606. 
Everaert, I., Mooyaart, A., Baguet, A., Zutinic, A., Baelde, H., Achten, E., ... Derave, W. (2011). Vegetarianism, female gender and increasing age, but not CNDP1 genotype, are associated with reduced muscle carnosine levels in humans. Amino acids, 40(4), 1221-1229.

Farrokhyar, F., Tabasinejad, R., Dao, D., Peterson, D., Ayeni, O. R., Hadioonzadeh, R.,Bhandari, M. (2015). Prevalence of vitamin D inadequacy in athletes: a systematic-review and meta-analysis. Sports medicine, 45(3), 365-378.

Fuhrman, J., Ferreri, D. M. (2010). Fueling the vegetarian (vegan) athlete. Current sports medicine reports, 9(4), 233-241.

Gibson-Smith, E., Storey, R.,Ranchordas, M. (2020). Dietary intake, body composition and iron status in experienced and elite climbers. Frontiers in Nutrition, 7.

Gilani, G. S., Cockell, K. A., Sepehr, E. (2005). Effects of antinutritional factors on protein digestibility and amino acid availability in foods. Journal of AOAC International, 88(3), 967-987.

Groufh-Jacobsen, S., Hess, S. Y., Aakre, I., Folven Gjengedal, E. L., Blandhoel Pettersen, K.,Henjum, S. (2020). Vegans, vegetarians and pescatarians are at risk of iodine deficiency in Norway. Nutrients, 12(11), 3555.

Haghighatdoost, F., Bellissimo, N., de Zepetnek, J. O. T., Rouhani, M. H. (2017). Association of vegetarian diet with inflammatory biomarkers: a systematic review and meta-analysis of observational studies. Public health nutrition, 20(15), 2713-2721.

Harris, R. C., Wise, J. A., Price, K. A., Kim, H. J., Kim, C. K., Sale, C. (2012). Determinants of muscle carnosine content. Amino acids, 43(1), 5-12.

Heller, S. (2019). Micronutrient needs of athletes eating plant-based diets. Nutrition Today, 54(1), 23-30.

Hernández-Martínez, C., Fernández-Rodríguez, L., Soriano, M. A.,Martínez-Sanz, J. M. (2020). Case Study: Body Composition Changes Resulting from a Nutritional Intervention on a Professional Vegan Powerlifter. Applied Sciences, 10(23), 8675.

Hietavala, E. M., Puurtinen, R., Kainulainen, H.,Mero, A. A. (2012). Low-protein vegetarian diet does not have a short-term effect on blood acid-base status but raises oxygen consumption during submaximal cycling. Journal of the International Society of Sports Nutrition, 9(1), 1-9.

Hietavala, E. M., Stout, J. R., Hulmi, J. J., Suominen, H., Pitkänen, H., Puurtinen, R., ...Mero, A. A. (2015). Effect of diet composition on acid-base balance in adolescents, young adults and elderly at rest and during exercise. European journal of clinical nutrition, 69(3), 399-404.

Ho-Pham, L. T., Vu, B. Q., Lai, T. Q., Nguyen, N. D.,Nguyen, T. V. (2012). Vegetarianism, bone loss, fracture and vitamin D: a longitudinal study in Asian vegans and non-vegans. European journal of clinical nutrition, 66(1), 75-82.

Ho-Pham, L. T., Nguyen, N. D.,Nguyen, T. V. (2009). Effect of vegetarian diets on bone mineral density: a Bayesian meta-analysis. The American journal of clinical nutrition, 90(4), 943-950.

Hsu, E. (2020). Plant-based diets and bone health: Sorting through the evidence. Current Opinion in Endocrinology, Diabetes and Obesity, 27(4), 248-252.

Huang, R. Y., Huang, C. C., Hu, F. B.,Chavarro, J. E. (2016). Vegetarian diets and weight reduction: a metaanalysis of randomized controlled trials. Journal of general internal medicine, 31(1), 109-116.

Hunt, J. R. (2002). Moving toward a plant-based diet: are iron and zinc at risk?. Nutrition reviews, 60(5), $127-134$.

Iannotti, L. L., Lutter, C. K., Bunn, D. A.,Stewart, C. P. (2014). Eggs: the uncracked potential for improving maternal and young child nutrition among the world's poor. Nutrition reviews, 72(6), 355-368. 
Jäger, R., Kerksick, C. M., Campbell, B. I., Cribb, P. J., Wells, S. D., Skwiat, T. M., ...Antonio, J. (2017). International society of sports nutrition position stand: protein and exercise. Journal of the International Society of Sports Nutrition, 14(1), 1-25.

Janssen, M., Busch, C., Rödiger, M., Hamm, U. (2016). Motives of consumers following a vegan diet and their attitudes towards animal agriculture. Appetite, 105, 643-651.

Wirnitzer, K. C. (2020). Vegan diet in sports and exercise-health benefits and advantages to athletes and physically active people: A narrative review. Int. J. Sports Exerc. Med, 6, 165.

Kerksick, C. M.,Kulovitz, M. (2013). Requirements of energy, carbohydrates, proteins and fats for athletes. In Nutrition and enhanced sports performance (pp. 355-366). Academic Press.

Kerksick, C. M., Wilborn, C. D., Roberts, M. D., Smith-Ryan, A., Kleiner, S. M., Jäger, R., ... Kreider, R. B. (2018). ISSN exercise \& sports nutrition review update: research \& recommendations. Journal of the International Society of Sports Nutrition, 15(1), 1-57.

Król, W., Price, S., Śliż, D., Parol, D., Konopka, M., Mamcarz, A., ...Braksator, W. (2020). A vegan athlete’s heart—is it different? Morphology and function in echocardiography. Diagnostics, 10(7), 477.

Kunstel, K. (2005). Calcium requirements for the athlete. Current sports medicine reports, 4(4), 203-206.

Larson-Meyer, E. (2018). Vegetarian and vegan diets for athletic training and performance. Sports Science Exchange, 29(188), 1-7.

Le, L. T.,Sabaté, J. (2014). Beyond meatless, the health effects of vegan diets: findings from the Adventist cohorts. Nutrients, 6(6), 2131-2147.

Lee, Y. M., Kim, S. A., Lee, I. K., Kim, J. G., Park, K. G., Jeong, J. Y., ...Lee, D. H. (2016). Effect of a brown rice based vegan diet and conventional diabetic diet on glycemic control of patients with type 2 diabetes: a 12week randomized clinical trial. PloS one, 11(6), e0155918.

Leischik, R.,Spelsberg, N. (2014). Vegan triple-ironman (raw vegetables/fruits). Case reports in cardiology, 2014.

Lemale, J., Mas, E., Jung, C., Bellaiche, M., Tounian, P.,Hepatology, F. S. P. (2019). Vegan diet in children and adolescents. Recommendations from the French-speaking Pediatric Hepatology, Gastroenterology and Nutrition Group (GFHGNP). Archives de Pédiatrie, 26(7), 442-450.

Li, D. (2011). Chemistry behind vegetarianism. Journal of agricultural and food chemistry, 59(3), 777-784.

Lynch, H., Johnston, C.,Wharton, C. (2018). Plant-based diets: Considerations for environmental impact, protein quality, and exercise performance. Nutrients, 10(12), 1841.

Lynch, H. M., Wharton, C. M.,Johnston, C. S. (2016). Cardiorespiratory fitness and peak torque differences between vegetarian and omnivore endurance athletes: a cross-sectional study. Nutrients, 8(11), 726.

Marsh, K., Zeuschner, C.,Saunders, A. (2012). Health implications of a vegetarian diet: a review. American Journal of Lifestyle Medicine, 6(3), 250-267.

McAfee, A. J., McSorley, E. M., Cuskelly, G. J., Moss, B. W., Wallace, J. M., Bonham, M. P.,Fearon, A. M. (2010). Red meat consumption: An overview of the risks and benefits. Meat science, 84(1), 1-13.

Medawar, E., Huhn, S., Villringer, A.,Witte, A. V. (2019). The effects of plant-based diets on the body and the brain: a systematic review. Translational psychiatry, 9(1), 1-17.

Mensink, R. P. (2005). Effects of stearic acid on plasma lipid and lipoproteins in humans. Lipids, 40(12), 12011205.

Menzel, J., Biemann, R., Longree, A., Isermann, B., Mai, K., Schulze, M. B., ...Weikert, C. (2020). Associations of a vegan diet with inflammatory biomarkers. Scientific reports, 10(1), 1-8. 
Nebl, J., Haufe, S., Eigendorf, J., Wasserfurth, P., Tegtbur, U.,Hahn, A. (2019). Exercise capacity of vegan, lactoovo-vegetarian and omnivorous recreational runners. Journal of the International Society of Sports Nutrition, 16(1), 1-8.

Nebl, J., Schuchardt, J. P., Ströhle, A., Wasserfurth, P., Haufe, S., Eigendorf, J., ...Hahn, A. (2019). Micronutrient status of recreational runners with vegetarian or non-vegetarian dietary patterns. Nutrients, 11(5), 1146.

Nebl, J., Schuchardt, J. P., Ströhle, A., Wasserfurth, P., Haufe, S., Eigendorf, J., ...Hahn, A. (2019). Micronutrient status of recreational runners with vegetarian or non-vegetarian dietary patterns. Nutrients, 11(5), 1146.

Nebl, J., Schuchardt, J. P., Wasserfurth, P., Haufe, S., Eigendorf, J., Tegtbur, U.,Hahn, A. (2019). Characterization, dietary habits and nutritional intake of omnivorous, lacto-ovo vegetarian and vegan runners-a pilot study. $B M C$ nutrition, 5(1), 1-14.

Norris, J. (2012). Iron in Vegetarian Diets. Vegetarian Nutrition 5-6.

Novakova, K., Kummer, O., Bouitbir, J., Stoffel, S. D., Hoerler-Koerner, U., Bodmer, M., ...Krähenbühl, S. (2016). Effect of 1-carnitine supplementation on the body carnitine pool, skeletal muscle energy metabolism and physical performance in male vegetarians. European journal of nutrition, 55(1), 207-217.

Orlich, M. J., Singh, P. N., Sabaté, J., Jaceldo-Siegl, K., Fan, J., Knutsen, S., ...Fraser, G. E. (2013). Vegetarian dietary patterns and mortality in Adventist Health Study 2. JAMA internal medicine, 173(13), 1230-1238.

Oussalah, A., Levy, J., Berthezène, C., Alpers, D. H.,Guéant, J. L. (2020). Health outcomes associated with vegetarian diets: An umbrella review of systematic reviews and meta-analyses. Clinical Nutrition, 39(11), 32833307.

Outila, T. A., KÄRKKÄINEN, M. U. M., SEPPÄNEN, R. H.,Lamberg-Allardt, C. J. E. (2000). Dietary intake of vitamin $\mathrm{D}$ in premenopausal, healthy vegans was insufficient to maintain concentrations of serum 25 hydroxyvitamin D and intact parathyroid hormone within normal ranges during the winter in Finland. Journal of the American Dietetic Association, 100(4), 434-441.

Owens, D. J.,Close, G. L. (2013). Vitamin D and athletic performance. Agro FOOD Industry Hi Tech, 24.

Pawlak, R., Lester, S. E.,Babatunde, T. (2014). The prevalence of cobalamin deficiency among vegetarians assessed by serum vitamin B12: a review of literature. European journal of clinical nutrition, 68(5), 541-548.

Pedlar, C. R., Newell, J.,Lewis, N. A. (2019). Blood biomarker profiling and monitoring for high-performance physiology and nutrition: current perspectives, limitations and recommendations. Sports Medicine, 49(2), 185198.

Phillips, F. (2005). Vegetarian nutrition. Nutrition Bulletin, 30(2), 132-167.

Phillips, S. M. (2016). The impact of protein quality on the promotion of resistance exercise-induced changes in muscle mass. Nutrition \& metabolism, 13(1), 1-9.

Phillips, S. M.,Van Loon, L. J. (2011). Dietary protein for athletes: from requirements to optimum adaptation. Journal of sports sciences, 29(sup1), S29-S38.

Read, S.,Grundy, E. (2012). Allostatic load-a challenge to measure multisystem physiological dysregulation. Pathways Node at NCRM.

Rocha, J. P., Laster, J., Parag, B.,Shah, N. U. (2019). Multiple health benefits and minimal risks associated with vegetarian diets. Current nutrition reports, 8(4), 374-381.

Rogerson, D. (2017). Vegan diets: practical advice for athletes and exercisers. Journal of the International Society of Sports Nutrition, 14(1), 1-15. 
Rosell, M. S., Lloyd-Wright, Z., Appleby, P. N., Sanders, T. A., Allen, N. E.,Key, T. J. (2005). Long-chain n-3 polyunsaturated fatty acids in plasma in British meat-eating, vegetarian, and vegan men-. The American journal of clinical nutrition, 82(2), 327-334.

Sahlin, K., Tonkonogi, M.,Söderlund, K. (1998). Energy supply and muscle fatigue in humans. Acta Physiologica Scandinavica, 162(3), 261-266.

Sakkas, H., Bozidis, P., Touzios, C., Kolios, D., Athanasiou, G., Athanasopoulou, E., ...Gartzonika, C. (2020). Nutritional status and the influence of the vegan diet on the gut microbiota and human health. Medicina, 56(2), 88.

San-Millán, I. (2019). Blood biomarkers in sports medicine and performance and the future of metabolomics. In High-Throughput Metabolomics (pp. 431-446). Humana, New York, NY.

Saunders, A. V., Davis, B. C.,Garg, M. L. (2013). Omega-3 polyunsaturated fatty acids and vegetarian diets. Medical journal of Australia, 199, S22-S26.

Schoenfeld, M. L. (2020). Nutritional considerations for the female vegan athlete. Strength \& Conditioning Journal, 42(4), 68-76.

Shomrat, A., Weinstein, Y.,Katz, A. (2000). Effect of creatine feeding on maximal exercise performance in vegetarians. European journal of applied physiology, 82(4), 321-325.

Shuler, F. D., Wingate, M. K., Moore, G. H.,Giangarra, C. (2012). Sports health benefits of vitamin D. Sports health, 4(6), 496-501.

Laidlaw, S. A., Shultz, T. D., Cecchino, J. T., Kopple, J. D. (1988). Plasma and urine taurine levels in vegans. The American journal of clinical nutrition, 47(4), 660-663.

Simopoulos, A. P. (2007). Omega-3 fatty acids and athletics. Current sports medicine reports, 6(4), 230-236.

Slavin, J. (2012). Dietary guidelines: Are we on the right path?. Nutrition Today, 47(5), 245-251.

Spencer, E. A., Appleby, P. N., Davey, G. K.,Key, T. J. (2003). Diet and body mass index in 38000 EPIC-Oxford meat-eaters, fish-eaters, vegetarians and vegans. International journal of obesity, 27(6), 728-734.

Spriet, L. L.,Whitfield, J. (2015). Taurine and skeletal muscle function. Current Opinion in Clinical Nutrition \& Metabolic Care, 18(1), 96-101.

Storz, M. A.,Helle, P. (2019). Atrial fibrillation risk factor management with a plant-based diet: A review. Journal of arrhythmia, 35(6), 781-788.

Thomas, D. T., Erdman, K. A.,Burke, L. M. (2016). Position of the Academy of Nutrition and Dietetics, Dietitians of Canada, and the American College of Sports Medicine: nutrition and athletic performance. Journal of the Academy of Nutrition and Dietetics, 116(3), 501-528.

Trexler, E. T., Smith-Ryan, A. E., Stout, J. R., Hoffman, J. R., Wilborn, C. D., Sale, C., ...Antonio, J. (2015). International society of sports nutrition position stand: Beta-Alanine. Journal of the International Society of Sports Nutrition, 12(1), 1-14.

T.C. Sağlık Bakanlığı (2016). Türkiye Beslenme Rehberi TÜBER 2015, Yayın No: 1031, Ankara

Vanacore, D., Messina, G., Lama, S., Bitti, G., Ambrosio, P., Tenore, G., ... Stiuso, P. (2018). Effect of restriction vegan diet's on muscle mass, oxidative status, and myocytes differentiation: a pilot study. Journal of cellular physiology, 233(12), 9345-9353.

Veleba, J., Matoulek, M., Hill, M., Pelikanova, T.,Kahleova, H. (2016). “A vegetarian vs. conventional hypocaloric diet: The effect on physical fitness in response to aerobic exercise in patients with type 2 diabetes." A parallel randomized study. Nutrients, 8(11), 671. 
van Vliet, S., Burd, N. A.,van Loon, L. J. (2015). The skeletal muscle anabolic response to plant-versus animalbased protein consumption. The Journal of nutrition, 145(9), 1981-1991.

Waldmann, A., Koschizke, J. W., Leitzmann, C., Hahn, A. (2004). Dietary iron intake and iron status of German female vegans: results of the German vegan study. Annals of nutrition and metabolism, 48(2), 103-108.

Watanabe, F., Yabuta, Y., Bito, T.,Teng, F. (2014). Vitamin B12-containing plant food sources for vegetarians. Nutrients, 6(5), 1861-1873.

Williams, C.,Rollo, I. (2015). Carbohydrate nutrition and team sport performance. Sports Medicine, 45(1), 13-22.

Wirnitzer, K., Boldt, P., Lechleitner, C., Wirnitzer, G., Leitzmann, C., Rosemann, T., Knechtle, B. (2019). Health Status of Female and Male Vegetarian and Vegan Endurance Runners Compared to Omnivores-Results from the NURMI Study (Step 2). Nutrients, 11(1), 29.

Yokoyama, Y., Levin, S. M.,Barnard, N. D. (2017). Association between plant-based diets and plasma lipids: a systematic review and meta-analysis. Nutrition reviews, 75(9), 683-698.

Yokoyama, Y., Nishimura, K., Barnard, N. D., Takegami, M., Watanabe, M., Sekikawa, A., ... Miyamoto, Y. (2014). Vegetarian diets and blood pressure: a meta-analysis. JAMA internal medicine, 174(4), 577-587.

Zhou, Jing, Jia Li, and W. Wayne Campbell. (2014). Vegetarian Athletes. Elsevier Inc.

Zimmer, J., Lange, B., Frick, J. S., Sauer, H., Zimmermann, K., Schwiertz, A., ...Enck, P. (2012). A vegan or vegetarian diet substantially alters the human colonic faecal microbiota. European journal of clinical nutrition, 66(1), 53-60. 